Digitized by the Internet Archive in 2016 


\section{Bird Populations on the Shoreline of Buffalo Lake: Identification of Priority Areas for Conservation}

David R. C. Prescott and Scott D. Stevens

Alberta Species at Risk Report No. 115

November 2007

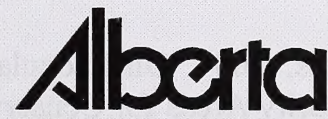


Publication No.: I/289

ISBN: 978-0-7785-6537-6 (Printed Edition)

ISBN: 978-0-7785-6538-3 (Online Edition)

ISSN: 1496-7219 (Printed Edition)

ISSN: 1496-7146 (Online Edition)

Cover Photographs: D. Prescott (clockwise from top: Franklin's Gull, Bald Eagle, Horned Grebe, Black-crowned Night-Heron [immature])

For copies of this report, contact:

Fish and Wildlife Division

Alberta Sustainable Resource Development

2nd Floor, 9920108 St.

Edmonton, Alberta T5K 2M4

OR

Visit our web site at:

http://www.srd.gov.ab.ca/fishwildlife/speciesatrisk/

A complete list of reports in this series can be viewed at:

http://www.srd.alberta.ca/fishwildlife/speciesatrisk/projectreports.aspx

This publication may be cited as:

Prescott, D. R. C., and S. D. Stevens. 2007. Bird Populations on the Shoreline of Buffalo Lake: Identification of Priority Areas for Conservation. Alberta Sustainable Resource Development, Fish and Wildlife Division, Alberta Species at Risk Report No. 115, Edmonton, AB. 27 pp. 


\section{TABLE OF CONTENTS}

LIST OF TABLES AND APPENDICES ….................................................................... iv

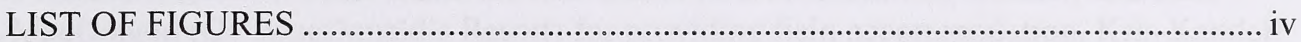

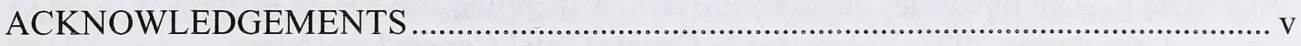

EXECUTIVE SUMMARY ……………………....................................................... vi

INTRODUCTION

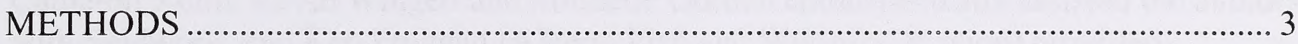

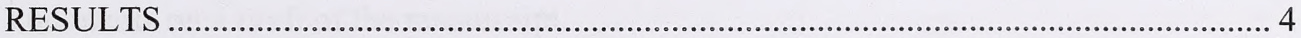

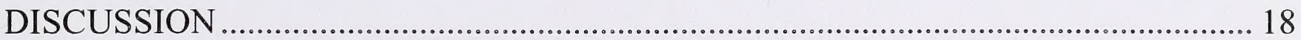

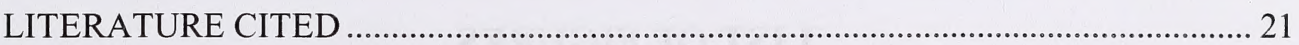




\section{LIST OF TABLES AND APPENDICES}

Table 1. Top 20 species in terms of their frequency of occurrence and mean abundance in point counts $(\mathrm{n}=687)$ along the shoreline of Buffalo Lake,

Appendix 1. List of species encountered during shoreline surveys on Buffalo Lake during 2007. Values for \% Counts, Total Counted and Mean Abundance are for species recorded during point counts $(n=687)$ along the lakeshore

\section{LIST OF FIGURES}

Figure 1. Map of Buffalo Lake and area...........................................

Figure 2. Distribution and abundance of 30 "Sensitive" species detected during

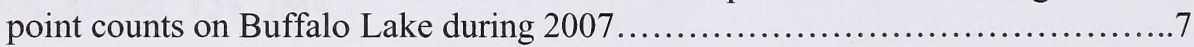

Figure 3. Distribution and abundance of six colonial waterbird species that are currently of "Secure" status in Alberta........................................15

Figure 4. Point count scores for the shoreline of Buffalo Lake in $2007 \ldots \ldots \ldots \ldots \ldots \ldots \ldots 17$

Figure 5. Distribution of amphibians and mammals encountered during bird surveys on Buffalo Lake during 2007 


\section{ACKNOWLEDGEMENTS}

We thank the following partners for financially supporting the project: Cordero Energy, Lacombe County, County of Stettler, Alberta Environment, and Alberta Public Lands and Forests Division. We also thank Ian McFarlane (Ducks Unlimited Canada) and Jean MacDonald (Ol' MacDonald's Resort) for providing field accommodation, Kris Kendell (Alberta Conservation Association) and Barry Cole (Alberta Public Lands and Forests Division) for providing manpower, and Don Page and Gavin Noonan (Alberta Sustainable Resource Development) for GIS support. We acknowledge the numerous landowners that granted access across their land, and for their interest in our activities. Cameron Nelin, Kevin Wingert and Michelle Gordon enthusiastically assisted the authors with fieldwork, and Ken Froggatt (Alberta Fish and Wildlife Division) provided comments on a draft of the manuscript. 


\section{EXECUTIVE SUMMARY}

Buffalo Lake is one of the largest lakes in central Alberta. The lake has been recognized by numerous authorities as being important for wildlife, and most notably for breeding waterbirds. Following stabilization of lake levels in the $1990 \mathrm{~s}$, and a thriving local economy, the lake is becoming increasingly popular for recreational and other developments. Several planning exercises are underway that will guide development and land use around Buffalo Lake in the future. In 2007, Alberta Fish and Wildlife Division, with support from local partners, conducted a comprehensive survey of bird species around Buffalo Lake. The goal was to prioritize shoreline areas based on the abundance and relative conservation importance of avian species around the lake, and to highlight areas where the protection of important bird habitats should be incorporated into land-use decisions.

A total of 687 circular point counts (100 $\mathrm{m}$ in radius, 6-min in duration) were completed around the entire shoreline of Buffalo Lake between 29 May and 30 June. Counts were centered on the shoreline of the lake, with half of each count sampling areas covered by water (including emergent vegetation), and the remaining half sampling upland habitats. Each count was assigned a value according to a formula that incorporated the abundance of each species observed in a count, and the risk of extirpation of each species in the province as determined by the General Status of Alberta Wild Species 2005. Values for counts were then divided into LOW (42.1\% of counts), MEDIUM (36.2\%), HIGH $(16.4 \%)$ or VERY HIGH $(5.2 \%)$ classes, reflecting the conservation value of each segment of shoreline around the lake.

A total of 125 species of birds were detected during point counts, and an additional 20 species of birds were encountered during other activities on the lake. Thirty of these species were classified being of "Sensitive" status in Alberta; no species of higher risk status ("At Risk" or "May be at Risk") were present in 2007. The resulting areas of HIGH or VERY HIGH conservation value were therefore heavily influenced by the distribution of "Sensitive" species, and occurred particularly where concentrations of such species occurred. These areas included the western parts of Secondary Bay, areas around Parlby Bay and the Narrows, emergent vegetation offshore from Scenic Sands, Bird Island, areas around the entrance and north end of Foreleg Bay, portions of Bashaw Bay, and the basin between Bashaw Bay and Foreleg Bay. These areas included significant colonies of several "Sensitive" species including Horned Grebes, Western Grebes, American White Pelicans, Great Blue Herons, Black-crowned Night-Herons, Forster's Terns and Black Terns, as well as significant aggregations of "Secure" species such as California Gulls, Franklin's Gulls, Ring-billed Gulls, Eared Grebes, Doublecrested Cormorants, and Marsh Wrens.

Water levels on Buffalo Lake were unusually high in 2007, but comparisons with historical records suggest that many of the high-priority areas are consistent across years. However, some species shift their distributions from year to year, and continued study of Buffalo Lake in other years, and during different times of the year are needed to fully assess the value of shoreline habitats to birds. 


\section{INTRODUCTION}

Buffalo Lake (Figure 1) is among the largest lakes in central Alberta (approximately 93.5 $\mathrm{km}^{2}$; Mitchell and Prepas 1990), with shoreline perimeter of about $100 \mathrm{~km}$. The lake is situated in the Aspen Parkland Ecoregion (Strong and Leggat 1991), and is surrounded by a mix of agricultural, industrial (primarily oil and gas extraction and processing), residential and recreational developments. Historically, Buffalo Lake experienced widely fluctuating water levels (Mitchell and Prepas 1990). In the 1970s, public interest in stabilizing lake levels to increase recreational opportunities became evident. This led to a series of engineering and impact assessments (see Environmental Management Associates 1991) that culminated in the completion, in 1995, of a project to pump water from the Red Deer River into the lake. This project was designed not only to stabilize the levels of Buffalo Lake, but to provide agricultural flood control, water supply for nearby municipalities, and the enhancement of fish and wildlife habitat (Gray et al. 1992). Lake stabilization and a thriving local economy have subsequently led to the acceleration of development on shorelines and adjacent areas in recent years.

Buffalo Lake has frequently been acknowledged for its importance to wildlife, and in particular, to birds. This recognition stems mainly from its value as a waterfowl production and staging area, and because of the presence of several large colonies of colonial waterbirds (Mitchell and Prepas 1990, Poston et al. 1990, Environmental Management Associates 1991, Bjorge 1992, Gray et al. 1992, Cottonwood Consultants 2000, Beyersbergen et al. 2004). The importance of the lake to other species of breeding birds has been poorly investigated (Environmental Management Associates 1991). This is despite the known richness of breeding species in the area (Semenchuk 1992), as well as the documented presence of several "at risk" ("Endangered", "Threatened" or "Special Concern") species around the lake (Alberta Fish and Wildlife Division, unpubl. data).

The lands around the lake (up to the 1-in-100 year flood line) are managed by Alberta Public Lands and Forests Division, which is currently leading a multi-agency team to determine the long-term management of these shorelines. Land-use planning is also being initiated by the Counties of Lacombe, Stettler and Camrose for areas around the lake. These exercises will have important influence on the availability and quality of wildlife habitat around Buffalo Lake, and the persistence of several species of high conservation importance. In 2007, Alberta Fish and Wildlife Division, with support from local partners, undertook a study to quantify the importance of shoreline areas of Buffalo Lake to avian species. This project, reported herein, aimed to prioritize shoreline areas based on the abundance and relative conservation importance of avian species around the lake, and to highlight areas where the conservation of important bird habitats should be incorporated into land-use decisions. 


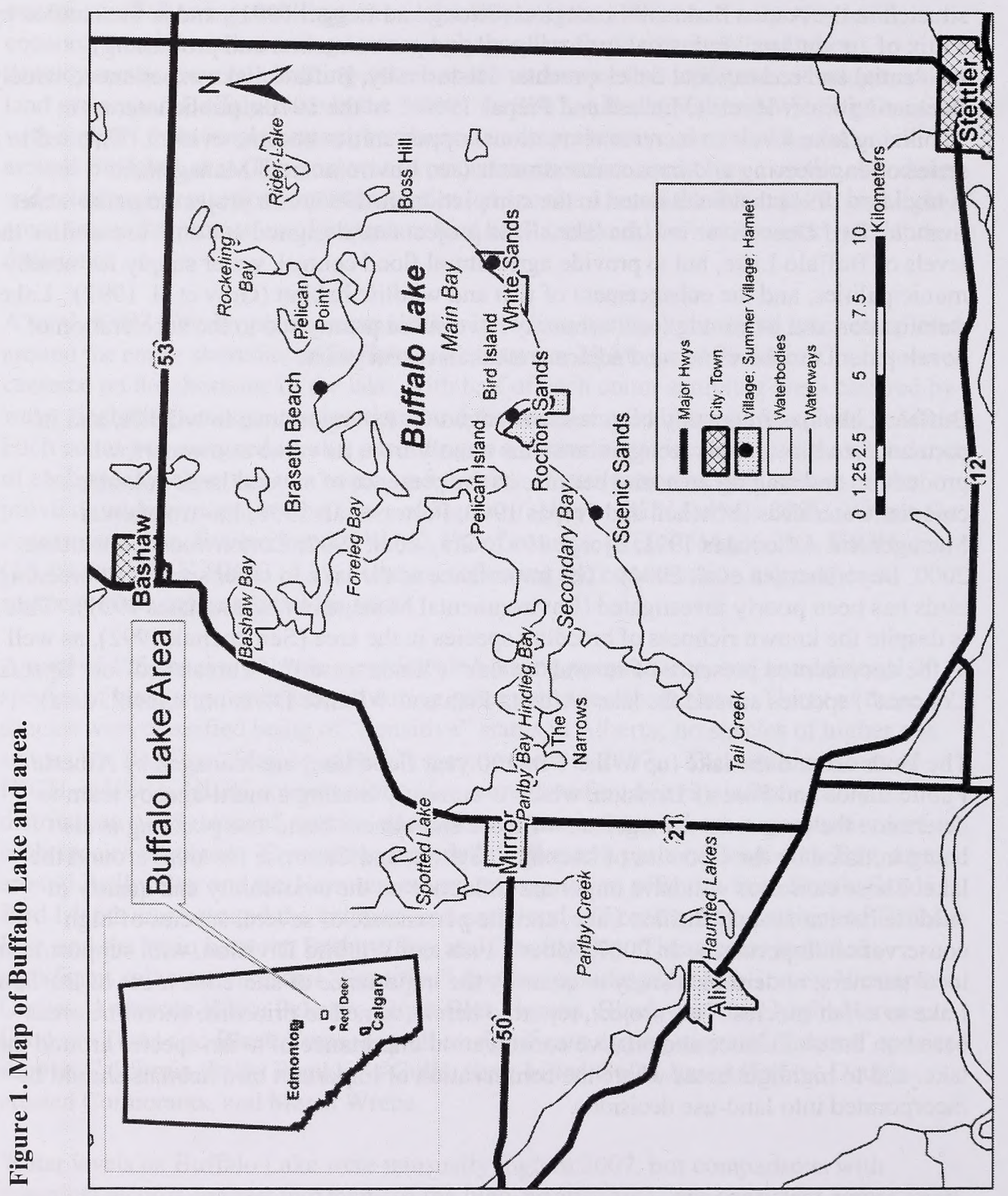




\section{METHODS}

Birds were surveyed in the spring and summer of 2007 using circular point counts (see Ralph et al. 1995 for general methodology) with a radius of $100 \mathrm{~m}$ positioned along the shoreline of the lake. Sample points were pre-selected, using 1999 colour imagery ( $1 \mathrm{~m}$ resolution) of Buffalo Lake and then converting paths to points using Hawth Tools in ArcGIS 9.1. Points $(n=931)$ were generated at $200 \mathrm{~m}$ intervals along the shoreline. The positioning of the count centres meant that on average, half of each count should sample areas covered by water (including emergent vegetation), with the remaining half sampling the upland habitats. In areas where the shoreline was highly irregular, the radii around pre-selected points often overlapped. If this overlap was $>30 \%$, certain points were deleted or rearranged to eliminate or reduce overlap between adjacent count circles. Points were added in a few areas where the digital polygon did not accurately represent the shoreline of the lake (generally islands and large patches of emergent vegetation in off-shore areas). The count circles were intended to sample, more or less, the shoreline buffer representing the 1-in-100-year high water mark that is managed by Alberta Public Lands as part of the Buffalo Lake water management project. The location of points also sampled areas (main basin and selected adjacent basins) that are under consideration for planning by the Buffalo Lake Integrated Shoreline Management Plan (BLISMP) initiative.

The geographical coordinates (decimal degrees, NAD 83) of all planned sample points were pre-loaded into GPS receivers (Garmin Map 60CSx, $76 \mathrm{CS}$ or $76 \mathrm{CSx}$ ) to facilitate navigation in the field. Points were then accessed by foot or watercraft (14' aluminum boat with $25 \mathrm{hp}$ outboard motor, canoe or kayak), depending on shoreline characteristics and logistics of access. Counters worked alone or in pairs, depending on their skill level, with members of pairs being varied to ensure consistency of count methodology. We arbitrarily began censuses on the eastern shore of the lake with the intention of working in a westerly direction. However, areas targeted for survey on different days were often determined by prevailing winds, so that counts were conducted on leeward shores whenever possible. Counts were generally conducted between 0600 and $1100 \mathrm{~h}$, during rainless periods when winds were $<20 \mathrm{~km} / \mathrm{h}$ and temperatures $<20^{\circ} \mathrm{C}$. Each count lasted for six minutes, during which all species seen or heard within the count circle were tallied. Birds flying through the count area that appeared not to be using habitats within the circle for any purpose were ignored. We also deleted species known to be migrants through the area. In general, we counted only birds seen or heard within the prescribed distance while standing at the point centre. However, we counted birds flushing out of circles as the observer approached the count center, if it was believed that proximity of the observer caused the birds to flee.

Segments of shoreline (i.e. $200 \mathrm{~m}$ units) around the lake were classified based on the number of species detected in each circle, in combination with their abundance and apparent risk status. The latter value was derived from status ratings determined by the General Status of Alberta Wild Species 2005 (Alberta Sustainable Resource Development 2007), which rates all species of birds (and other wildlife and plants) based on their expected risk of extirpation in the province. In this system, species are evaluated on 
factors such as their current abundance and population size in the province, trend in population size and distribution, and threats to populations and habitats. Each species is then classified into one of the following groups which reflect their priority to wildlife managers: "Alien/Exotic", "Secure", "Sensitive", "May be at Risk", or "At Risk" (other minor categories are defined, but omitted here). We assigned numerical values of 1,10 , 100,1000 and 10,000, respectively, to species in these categories, and derived a total score for each count by calculating the product of abundance and status score for each species, and summing these products over all species observed in a count. For example, a count where we observed two House Sparrows (status "Alien/Exotic"; score=1), 10 Redwinged Blackbirds (status "Secure"; score $=10$ ), and two Horned Grebes (status "Sensitive"; score $=100)$ would have an overall score of $(2 * 1)+(10 * 10)+(2 * 100)=302$. Based on the range of scores calculated over all counts on the lake, we later divided up the counts into VERY HIGH, HIGH, MEDIUM and LOW importance, such that no less than $40 \%$ of counts fell into the LOW category, and no more than $5 \%$ of scores fell into the VERY HIGH category.

Count circles of 100-m radius can not detect the full suite of species using habitats around Buffalo Lake. For example, rare or uncommon species may occasionally be detected only when traveling between points, or while performing other tasks around the lake (general reconnaissance, visits to landowners, etc.). We compiled observations of all bird species seen within $2 \mathrm{~km}$ of the shoreline of the lake using classification of The Atlas of Breeding Birds of Alberta (Semenchuk 1992). Classes of observation included "migrant" (birds seen in the area, but considered to be en route to or from breeding areas distant from Buffalo Lake), "possible" breeders (observed in suitable breeding habitat at times when breeding is likely to occur), "probable" breeders (observations of paired or territorial birds, courtship behavior, or behaviors suggesting the presence of an unseen nest), and "confirmed" breeders (birds observed with nests, eggs or young, or seen carrying food or faecal sacs). We also documented the location of significant colonies of waterbirds and other species in cases where these aggregations were not positioned within count circles. Observations of mammals, amphibians and reptiles were recorded when encountered.

\section{RESULTS}

Substantial winter snowfall and spring rains meant that water levels on Buffalo Lake in 2007 were higher than in recent years. These conditions meant that many of the predetermined count centers were in shallow water, rather than being on the edge of dry ground as intended. Nevertheless, we conducted surveys from these points, but recognized that this placement may have biased bird counts towards aquatic and semiaquatic species, and underrepresented the abundance of land birds within $100 \mathrm{~m}$ of the "normal" lake edge.

Five different observers participated in the completion of 687 counts on 25 days between 29 May and 30 June 2007. These observers completed a mean of $27.48 \pm 1.74$ (SE) counts/day (range: 10-41). All but 33 (4.8\%) of the counts were conducted before 1100 
h. Only seven counts $(1.0 \%)$ were completed after $1200 \mathrm{~h}$, and all of these were conducted during the first two field days of the study (29 May and 1 June), when birds were highly active and observable.

A total of 125 species were encountered during point counts. This total includes only species that were likely to breed in the area, with $55.2 \%$ considered to be "confirmed" breeders, $20.8 \%$ being "probable" breeders, and $24.0 \%$ being "possible" breeding species (Appendix 1). Two species, the Sandhill Crane (1 count) and Herring Gull (2 counts), are not known to breed in the Buffalo Lake area. However, these species were retained in the point count database because suitable habitat for breeding occurs on the lake, and breeding activity can not be ruled out due to the proximity of Buffalo Lake to known summer ranges of these species (Semenchuk 1992). Even if breeding did not occur, both of these species were uncommon, and would have contributed little to the overall rating of counts on the lake. The mean number of species per count was $12.30 \pm 0.12$ (range: 2 22 ), with the mean number of individuals being $31.71 \pm 1.85$ (range: 6-828) per count.

The top 20 species in terms of frequency of encounters and mean abundance per count are shown in Table 1, with values for all species encountered shown in Appendix 1. The most frequently encountered species were Red-winged Blackbirds (66.1\% of counts), followed by American Coots (60.6\%) and Clay-colored Sparrows (59.5\%). Red-winged Blackbirds also had the highest abundance per count of any species (2.20), followed by Black Terns (2.04) and Franklin's Gulls (1.98).

\section{Table 1. Top 20 species in terms of their frequency of occurrence and mean} abundance in point counts $(n=687)$ along the shoreline of Buffalo Lake, 2007. See Appendix 1 for complete listing.

\begin{tabular}{|c|c|}
\hline Frequency of Counts (\%) & Mean Abundance per Count \\
\hline Red-winged Blackbird (66.1) & Red-winged Blackbird (2.20) \\
\hline American Coot (60.6) & Black Tern (2.04) \\
\hline Clay-colored Sparrow (59.5) & Franklin's Gull (1.98) \\
\hline Savannah Sparrow (55.3) & California Gull (1.75) \\
\hline House Wren (48.5) & Yellow-headed Blackbird (1.38) \\
\hline Yellow Warbler (48.0) & American Coot (1.19) \\
\hline Yellow-headed Blackbird (39.0) & Savannah Sparrow (1.19) \\
\hline Blue-winged Teal (38.4) & Blue-winged Teal (1.15) \\
\hline Red-necked Grebe (38.0) & Forster's Tern (1.14) \\
\hline Black Tern (37.6) & Clay-colored Sparrow (1.11) \\
\hline Tree Swallow (35.7) & Eared Grebe (1.08) \\
\hline Mallard (34.8) & Mallard (1.08) \\
\hline Least Flycatcher (32.6) & Red-necked Grebe $(0.98)$ \\
\hline American Crow (28.4) & House Wren $(0.91)$ \\
\hline Forster's Tern (25.9) & American White Pelican $(0.80)$ \\
\hline Sora $(24.3)$ & Tree Swallow $(0.78)$ \\
\hline Gadwall (24.2) & Yellow Warbler $(0.77)$ \\
\hline Warbling Vireo (22.7) & Gadwall $(0.55)$ \\
\hline Wilson's Snipe (21.5) & Least Flycatcher $(0.51)$ \\
\hline American Robin (21.4) & American Crow (0.50) \\
\hline
\end{tabular}


The majority (73.6\%) of the 125 species encountered during point counts are currently listed as being of "Secure" status in Alberta (Appendix 1). A total of 30 species (24.0\%) are currently listed as being "Sensitive", with three species ( $2.4 \%$ being considered to be "Alien/Exotics"). There were no species found during point counts in 2007 that are currently considered to be "May be At Risk" or "At Risk" in Alberta. The distributions of sensitive species on the lake are shown in Figure 2. Many species were relatively uncommon and sporadic in occurrence (11 species were found in four counts or less). Other species were very common on certain areas of the lake (e.g., colonial waterbirds such as Western Grebe, American White Pelican, Black-crowned Night-Heron, Forster's Tern and Black Tern); whereas others occurred frequently, but at low abundance around much of the lake (e.g. Sora, Least Flycatcher and Baltimore Oriole). In general, most concentrations of "Sensitive" species occurred on the western and northern areas of the lake. This is also true of six species of colonial waterbirds that are currently listed as "Secure" in Alberta (Figure 3). These species (Ring-billed, Franklin's and California Gulls, Eared Grebes, Double-crested Cormorants and Marsh Wrens) occur in significant concentrations on Buffalo Lake.

Classification of point counts based on the species present and their risk status resulted in scores ranging from 60 to 31050 . These scores were grouped into priority classes as follows: LOW (scores $<500 ; 42.1 \%$ of counts), MEDIUM (scores of 500-999; 36.2\% of counts), HIGH (scores of 1000-1999; 16.4\% of counts) and VERY HIGH (scores $\geq 2000$; $5.2 \%$ of scores). Given the importance of "Sensitive" species in calculating scores, it follows that most areas of the HIGH and VERY HIGH importance occurred on the western and northern parts of Buffalo Lake (Figure 4). The highest ratings occurred in areas with large aggregations of colonial waterbirds, and especially areas where concentrations of several species occur in the same areas. These include the western parts of Secondary Bay (see Figure 1 for descriptions), areas around Parlby Bay and the Narrows, the emergent vegetation offshore from Scenic Sands, Bird Island, areas around the entrance and north end of Foreleg Bay, portions of Bashaw Bay, and the basin between Bashaw Bay and Foreleg Bay.

Twenty species of birds that were not seen during point counts were detected during other activities on the lake in 2007 (Appendix 1). These included eight species that were migrating to or from the breeding grounds to the north, 11 "possible" breeders, and one "probable" breeder (Western Kingbird). All but five of these species are considered to be of "Secure" status, with the remainder being two "Sensitive" species (Turkey Vulture and Swainson's Hawk), two species of "Undetermined" status (Short-billed Dowitcher and Yellow Rail), and one "Exotic/Alien" (Ring-necked Pheasant).

The distribution of seven species of mammals and three species of amphibians encountered during point-count surveys are shown in Figure 4. Our surveys were not designed to survey these animals, so observations are not necessarily representative of their actual distribution or abundance around the lake. However, the distributions of Beaver (Castor canadensis) and Muskrat (Ondatra zibethicus) are likely quite accurate, with these species being found in relatively undisturbed areas of the lake. All species of mammal and amphibian that we 

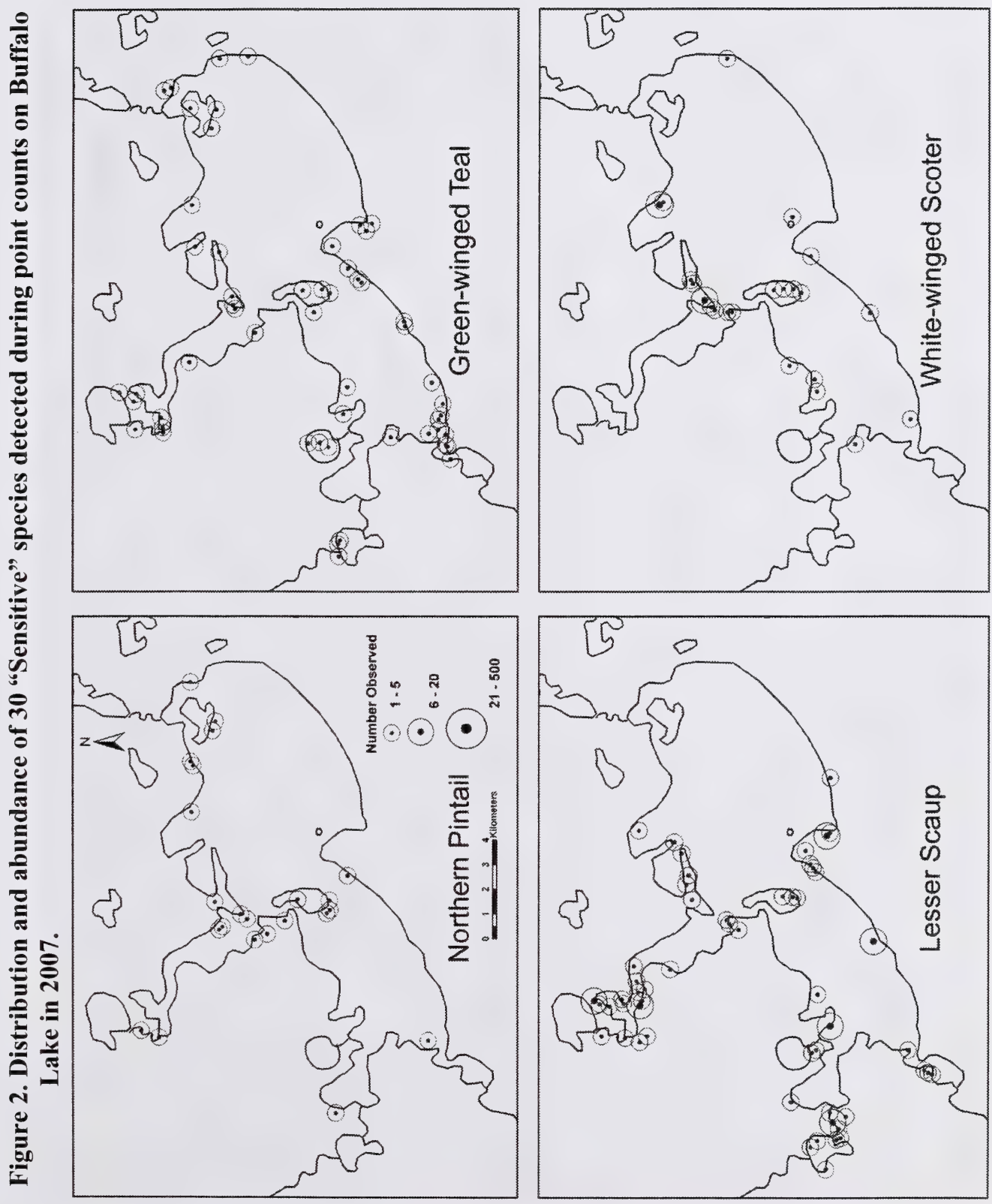

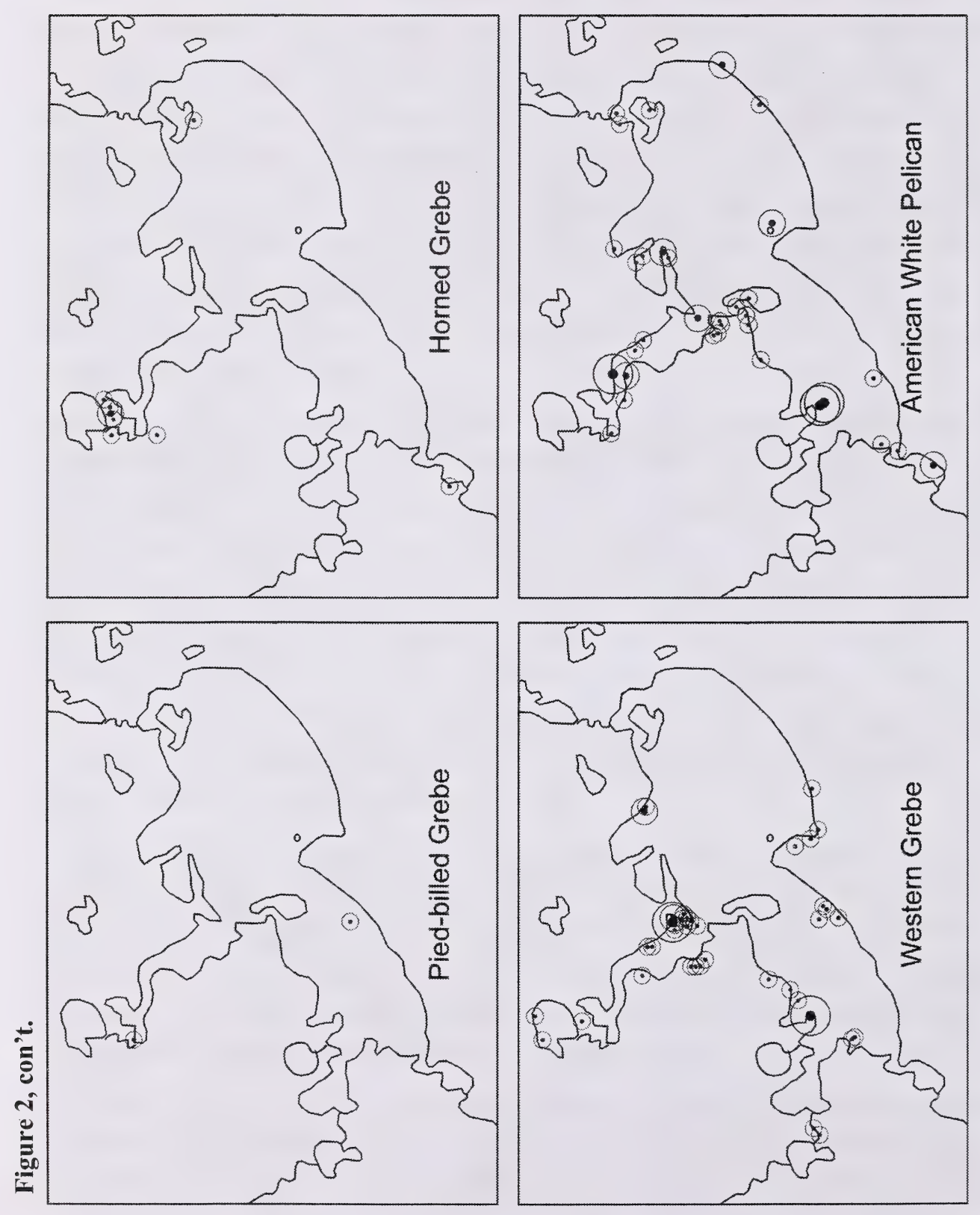

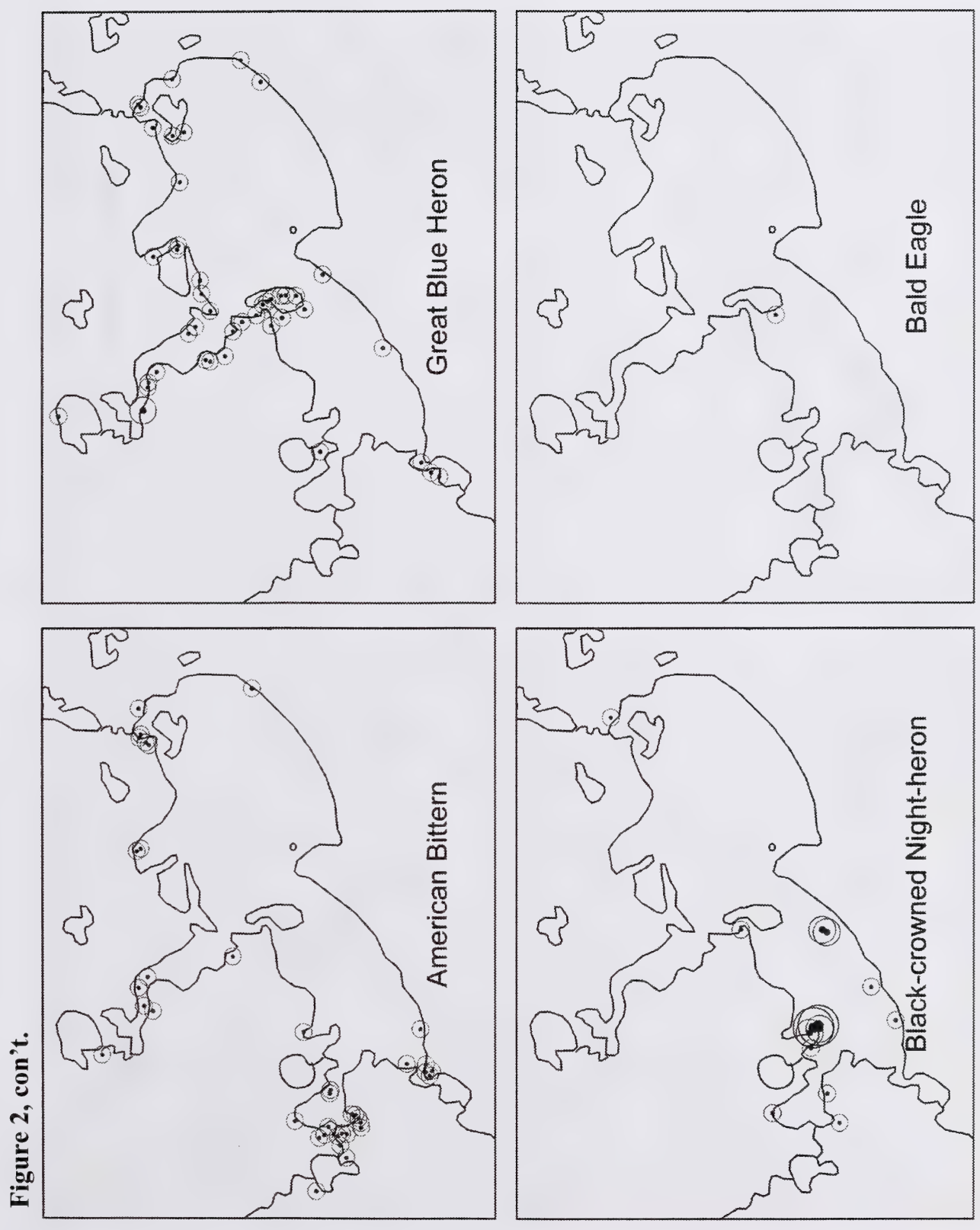

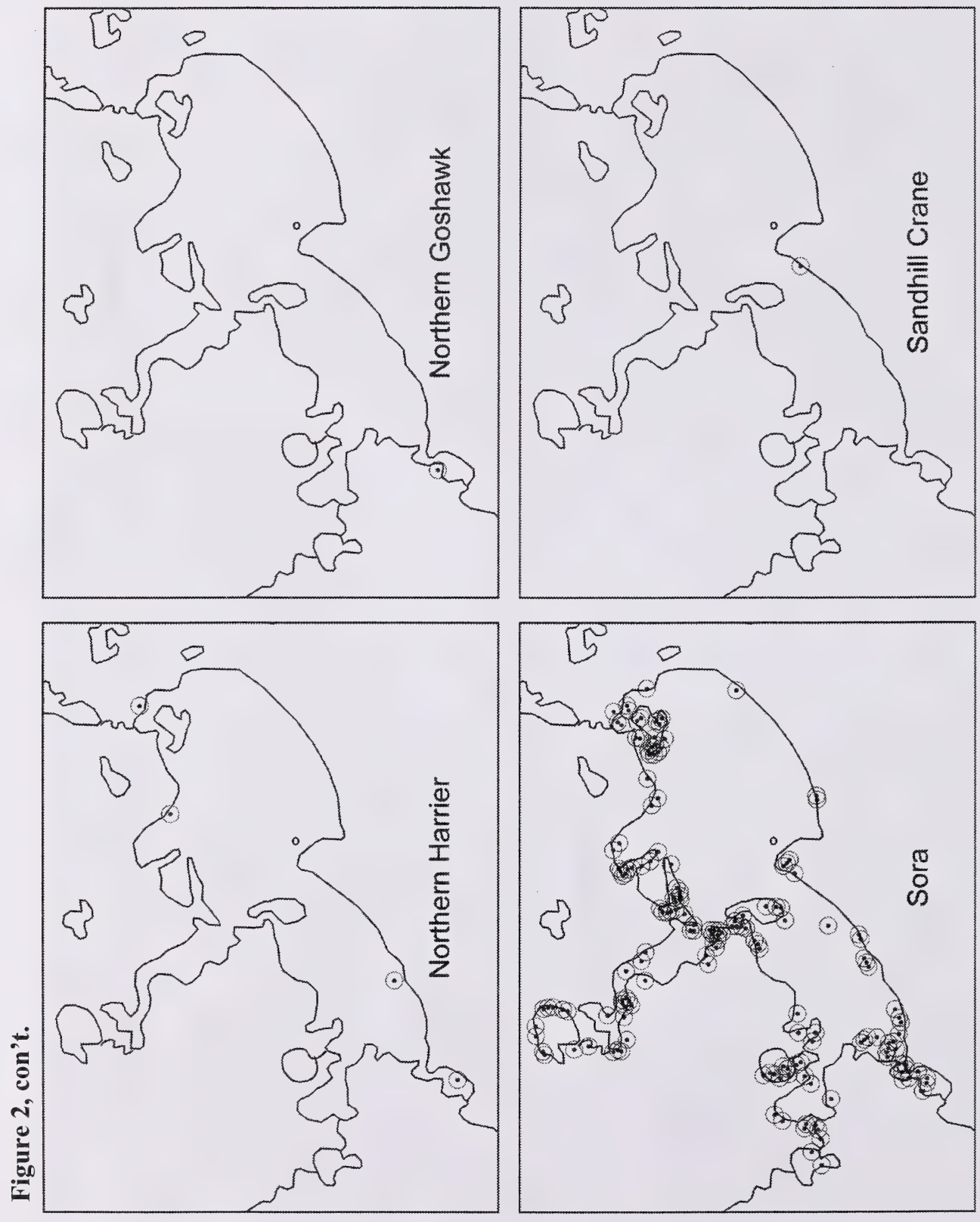

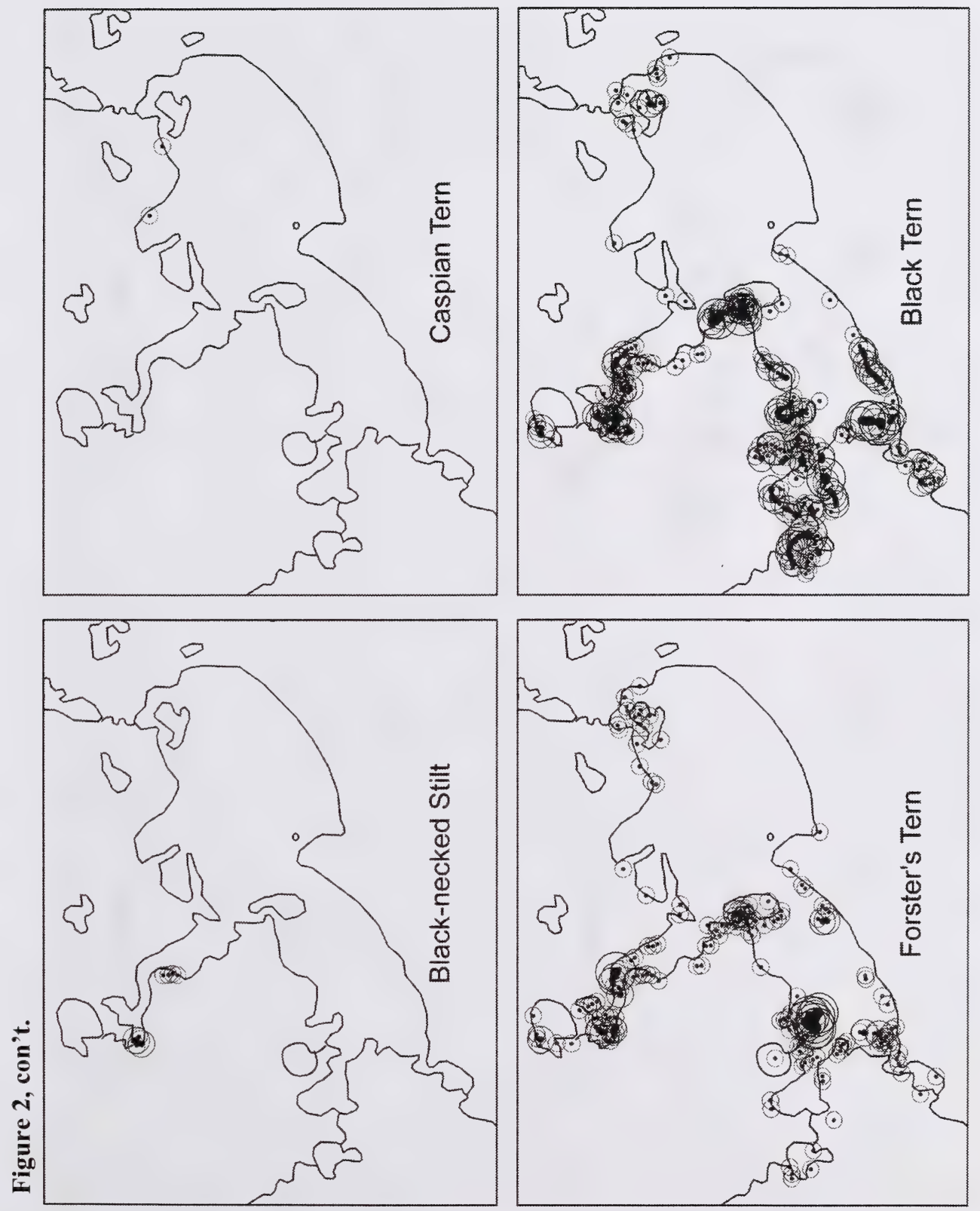

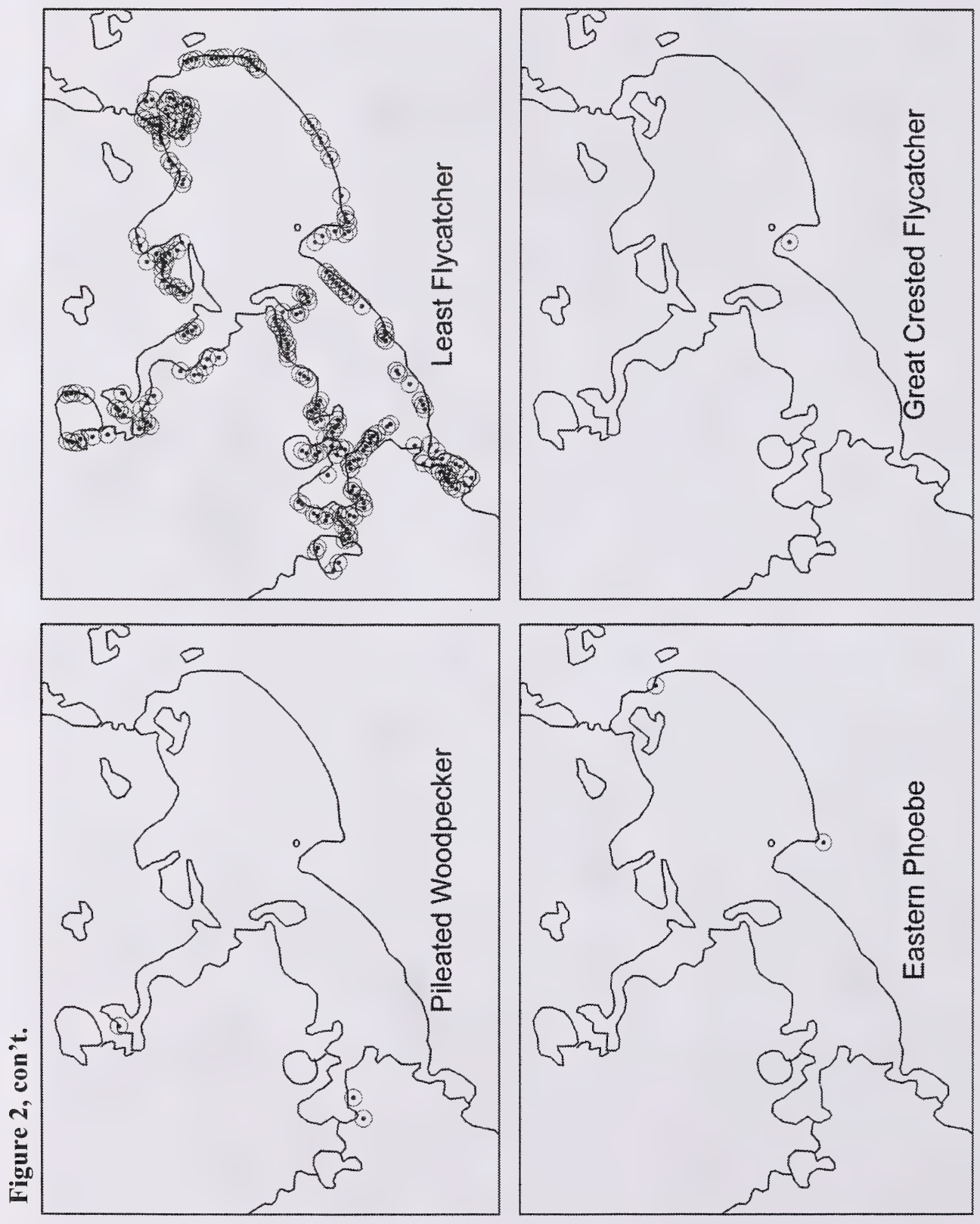

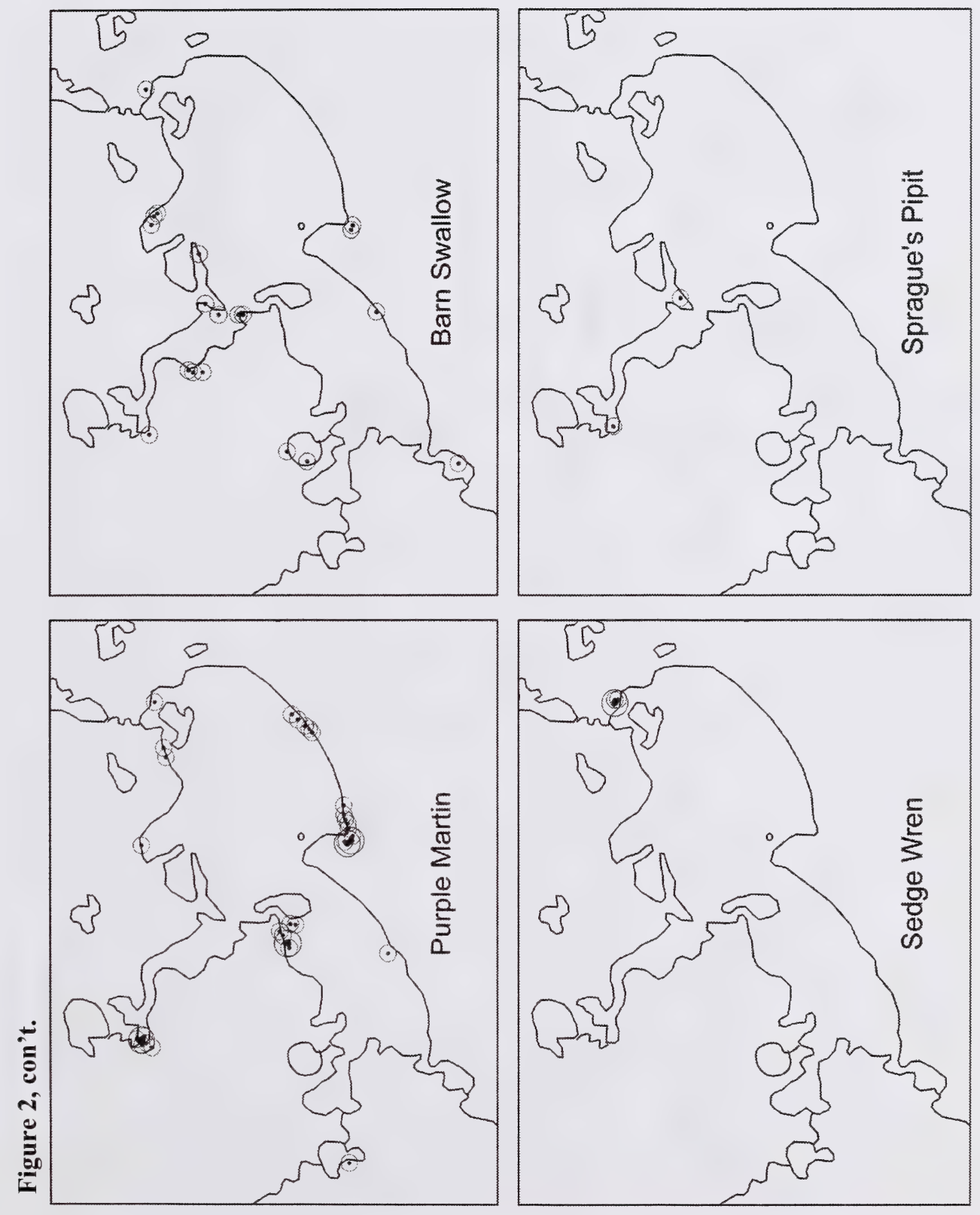

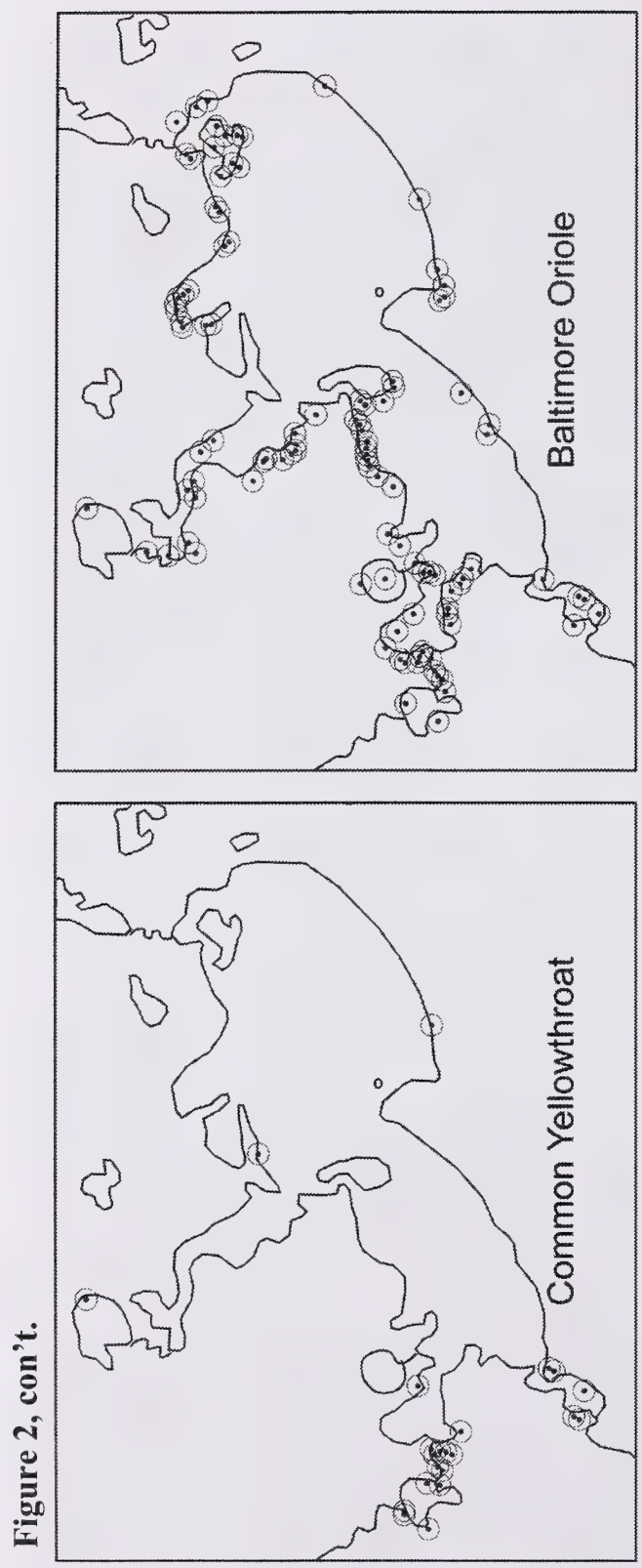

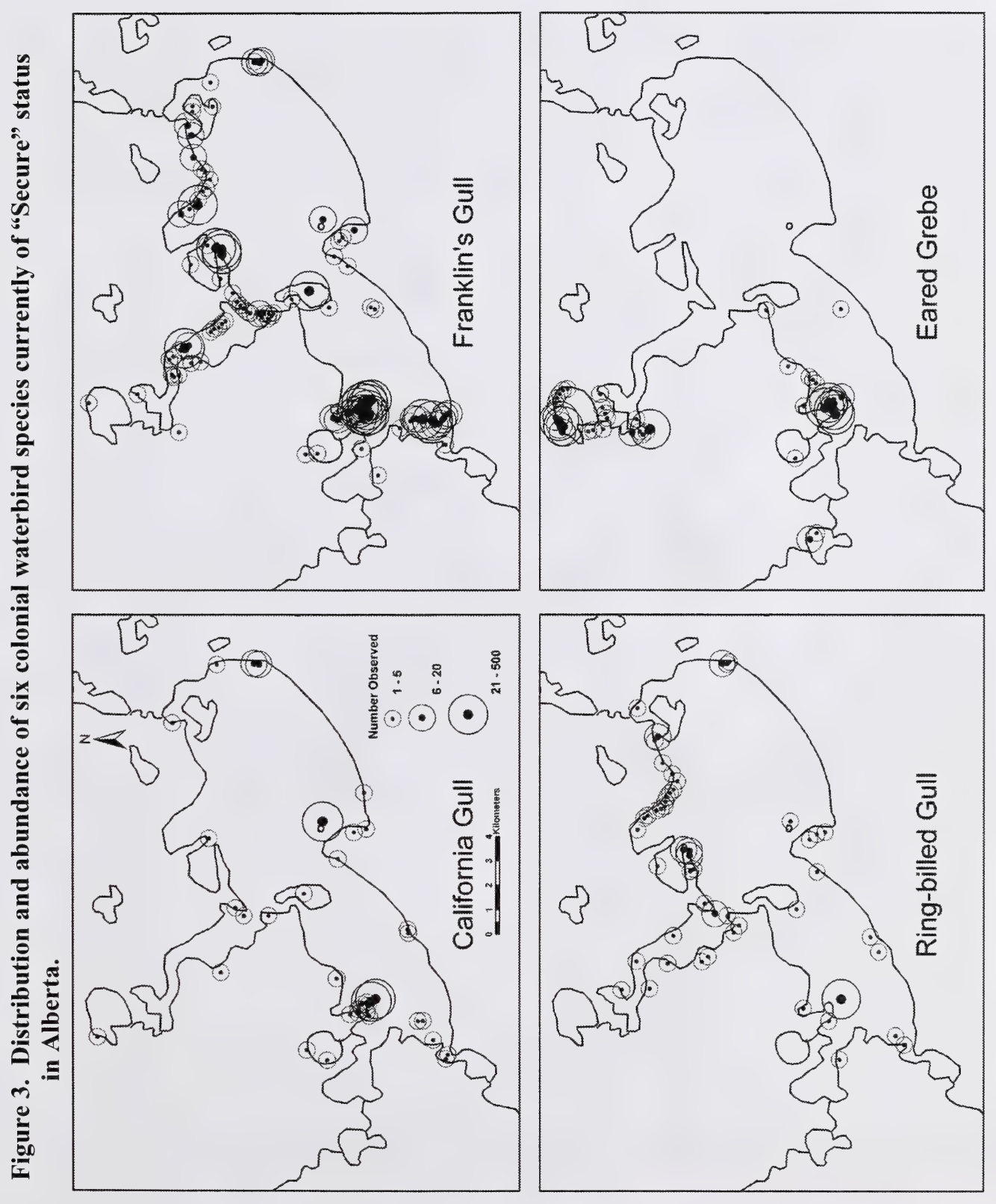

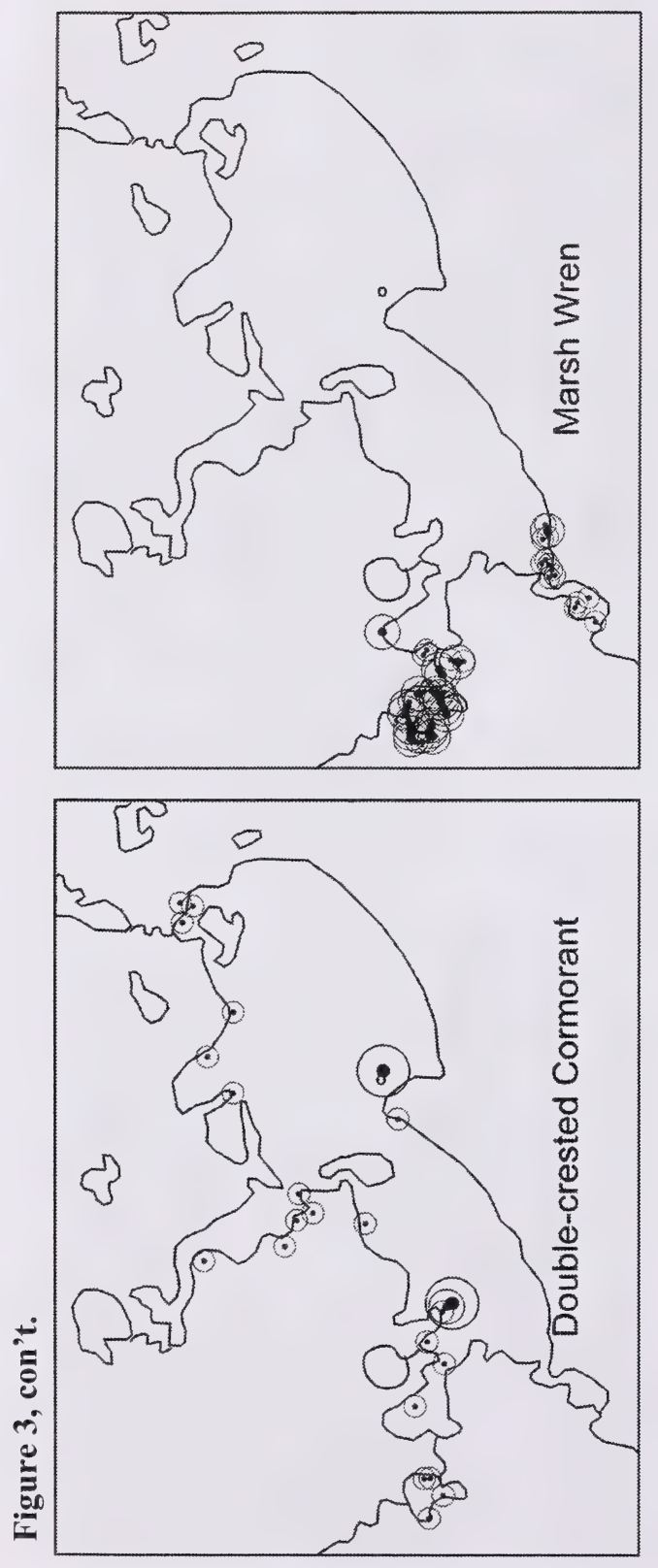


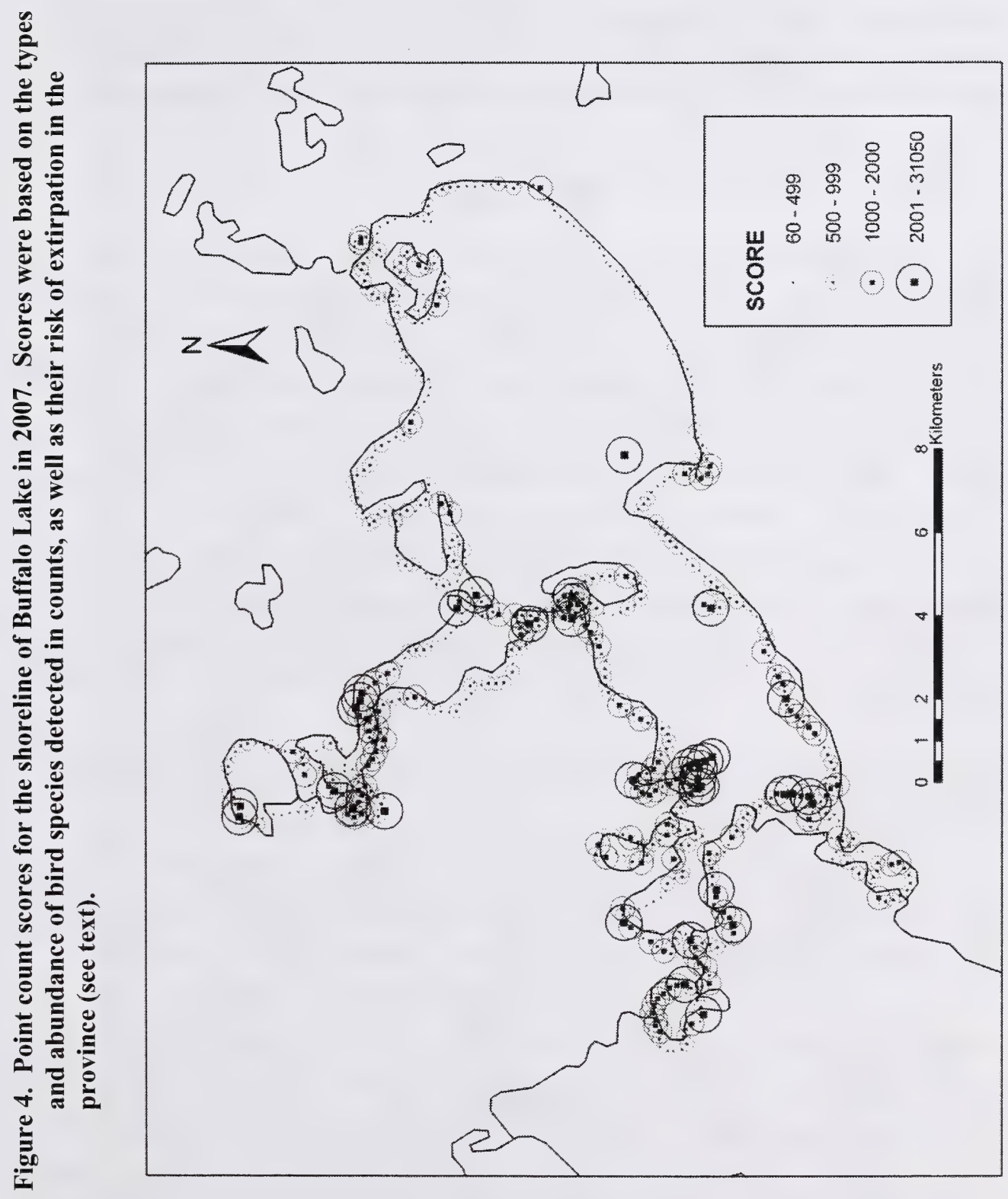


encountered are "Secure" species in Alberta, with the exception of the Canadian Toad. This species, which is currently listed as a "May Be At Risk" species (Alberta Sustainable Resource Development 2007), has disappeared from many areas of Alberta in recent years (Hamilton et al. 1998, Alberta Sustainable Resource Development 2007). Several observations of Canadian Toads were made along Tail Creek and adjacent parts of Buffalo Lake during bird surveys in 2007 (Figure 5). Up to 100 young-of-the year were seen along Tail Creek during amphibian studies in July (Prescott, unpubl. data).

\section{DISCUSSION}

Our results confirm Buffalo Lake to be a regionally significant lake for aquatic, semiaquatic and land birds. In total, we tallied 145 species on and around the lake during the breeding season, including 137 species that are at least potential breeders. This total is higher total than recorded during extensive surveys by Gray et al. (1992), who tallied 122 species during the breeding and migration periods, including approximately 101 species that would be expected to breed in the area. Also significant is the occurrence of 30 "Sensitive" species, many of which are colonial nesters. For many of these species, Buffalo Lake supports the largest populations in central Alberta. The lake is undoubtedly of high importance outside of the breeding season as well. As examples, Gray et al. (1992) recorded 20 species of migrant shorebirds during relatively infrequent surveys in a single year. The lake is also known to support large concentrations of staging waterfowl (Poston et al. 1990, Gray et al. 1992), and upland areas around the lake provide a diversity of habitats to support migratory and wintering land birds. Over the course of a single year, more than 200 species of birds would be expected to use the habitats around Buffalo Lake.

During 2007, Buffalo Lake experienced the highest water levels since the stabilization project was completed in 1995 (D. Neis, pers. comm.). From descriptions in previous reports, water was significantly higher than during surveys by Bjorge (1992), Gray et al. (1992), Potter et al. (2003) and between 2004 and 2006 (Prescott, unpubl. data). This resulted in high numbers of birds that prefer wet meadow and shallow emergent habitats (e.g. Wilson's Snipe, Black-necked Stilt, Wilson's Phalarope, Black Tern, Red-necked Grebe and American Bittern), and lower abundance of species that occupy exposed shorelines or rocky islands (e.g. Spotted Sandpiper, Killdeer, Common Tern). Eared Grebes were far rarer in 2007 than they were in 2002 (Potter et al. 2003), or between 2004 and 2006 (Prescott, unpubl. data), with populations in 2007 being largely restricted to four relatively small colonies located in Parlby Bay, Bashaw Bay, the northwestern side of Secondary Bay, and the basin between Bashaw Bay and Foreleg Bay (Figure 3). The high water levels in 2007 may have caused the relocation of several waterbird colonies relative to the position occupied during the past few years. For example, a large colony of White Pelicans, Double-crested Cormorant, and Ring-billed Gulls occupying Bird Island for the past few years was much smaller in 2007, with the majority of birds moving to a newly formed island (formerly a peninsula) on the northwestern shore of 

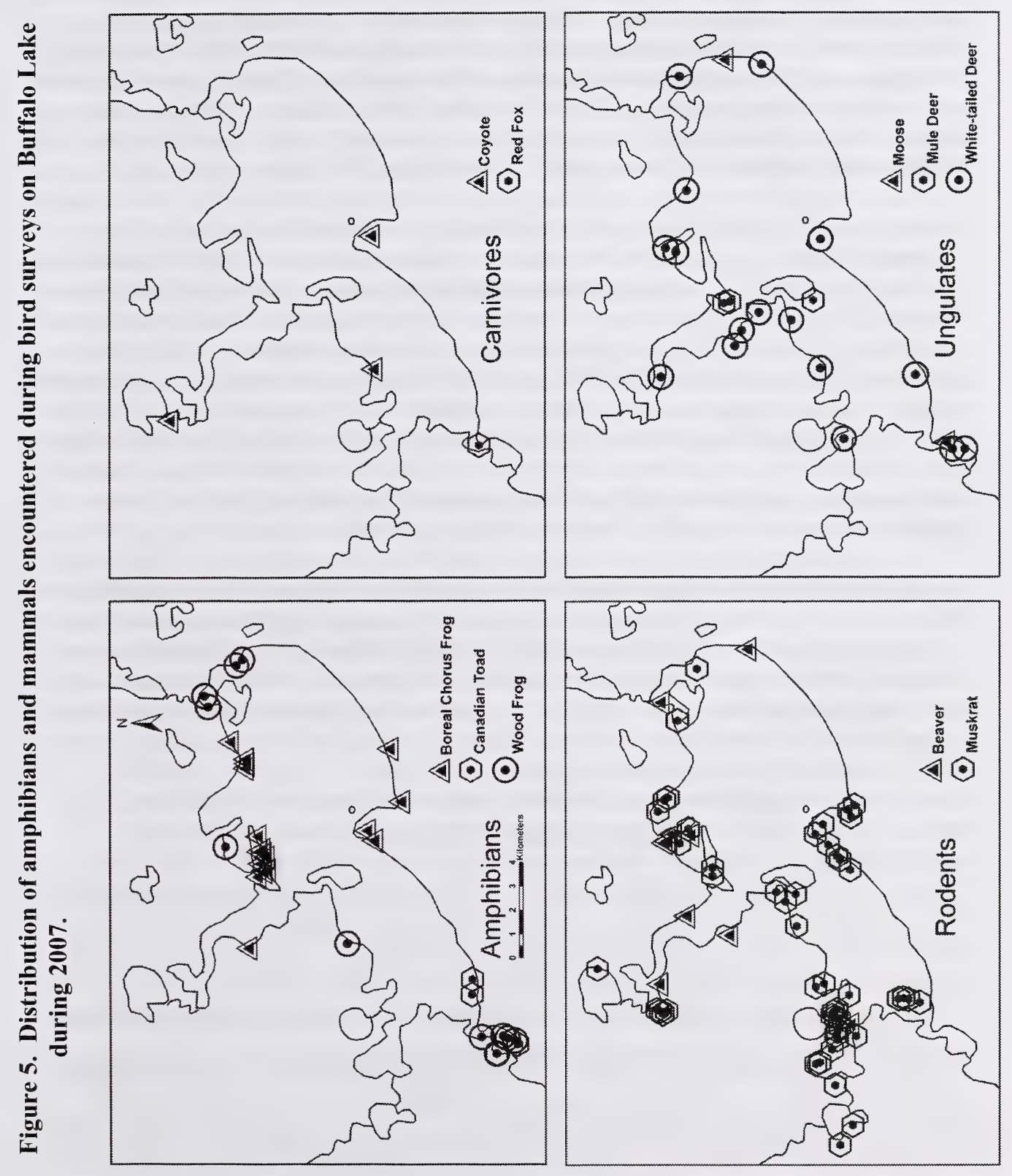
Secondary Bay. The major Franklin's Gull colony shifted from the emergent vegetation offshore of Scenic Sands (Potter et al. 2003) to near the outlet of Tail Creek, and to the northwest side of Secondary Bay in 2007 (Figure 3). Other significant waterbird colonies appeared to be unaffected by higher water levels. For example, the colony of Blackcrowned Night-Herons has occupied the same location in the emergent vegetation offshore from Scenic Sands during varying water conditions (Bjorge 1992, Potter et al. 2003; this study). Two provincially significant colonies of the Western Grebe have been in the same location since at least 2002 (Potter et al. 2003, Berg et al. 2004, Prescott, unpubl. data) and the colony of Great Blue Herons (currently about 55 nests) on the Pelican island has been in place for over 35 years (Allen 1987, Bjorge 1992).

It should be noted that high water levels temporarily eliminated habitat for the endangered Piping Plover (Charadrius melodus) on areas adjacent to Buffalo Lake (Rider Lake and Rockeling Bay) where they have nested in recent years (Alberta Piping Plover Recovery Team 2006). Recession of water levels in future years will undoubtedly create unvegetated shorelines to support plover populations. Lower water levels may prompt the return of Piping Plovers to Buffalo Lake itself in the next few years. The species has not been reported on the lake since 1989 (Goossen et al 2000, Alberta Fish and Wildlife, unpubl. data), although suitable substrates occur on several portions of the lake but have been covered by vegetation for the last decade or more. The presence of this endangered species will be a significant addition to the avifauna of Buffalo Lake, and will have implications for the protection of certain shorelines on the lake.

Our analysis of priority areas for conservation identified the following sites: western parts of Secondary Bay, Parlby Bay and the Narrows, the emergent vegetation offshore from Scenic Sands, Bird Island, the entrance and north end of Foreleg Bay, Bashaw Bay and the basin between Bashaw Bay and Foreleg Bay. The atypical water levels mean that shoreline values calculated from work in 2007 will not be identical to values calculated during years when water levels were much lower. Even so, our determination of priority areas is remarkably similar to the conclusions of Gray et al. (1992) who conducted surveys prior to stabilization, and apparently under much lower water conditions. These authors listed several "critical areas" for protection, based not only on breeding waterbirds, but also migrant waterfowl and shorebirds, rare plants, and other wildlife species. These areas included Bashaw Bay, Tail Creek and Tail Bay (presumably the outlet of Buffalo Lake at Tail Creek), the Narrows, several islands where colonial waterbirds occur, Parlby Bay, Hindleg Bay and Foreleg Bay ${ }^{1}$. The similarity in priority areas derived from different methodologies and during vastly different water levels lends weight to these areas being of high conservation value under a broad range of conditions.

The areas identified as high priorities for conservation are generally areas with extensive emergent vegetation, and relatively remote and undisturbed by human activity. It is hoped that land-use planning exercises underway on Buffalo Lake will include protective measures for these areas of significant avian value. Such measures could include: zoning areas for development based on sensitivity of shorelines; establishing speed limits and

\footnotetext{
' Gray et al. (1992) also cited Rider Lake, Rockeling Bay and Spotted Lake as "critical areas" (see Figure 1 for locations). These sites were not included in the survey area in 2007.
} 
restricted areas for boaters and all-terrain vehicle users; increasing the awareness of residents and other lake users about sensitive areas; and the establishment of seasonal sanctuaries to exclude human disturbance during the nesting season. Such a sanctuary is currently in place on Bird Island, but this protected area includes only a single sensitive species (American White Pelican), and most individuals of this species nested away from Bird Island in 2007. The existing sanctuary offers no protection for any of the other sensitive species identified on the lake. Perhaps the most significant of these species currently occurring on the lake is the Western Grebe. The species has recently been declared to be a species of "Special Concern" in Alberta, and will be re-evaluated in the next two years for possible reclassification as a "Threatened" species under Alberta's Wildlife Act. When approving the current designation in January 2007, the Minister of Sustainable Resource Development declared that all known colonies of Western Grebes in Alberta be afforded immediate protection. Given this, the establishment of seasonal sanctuaries, which are designated under Alberta's Wildlife Act, should be strongly considered for parts of Buffalo Lake that support Western Grebes, and perhaps other species. Protection of the major colony on the northwestern shore of Secondary Bay (Figure 2) would also include protection for many other colonial species, including Black and Forster's Terns, Black-crowned Night-Herons, American White Pelicans, California, Ring-billed and Franklin's Gulls, Eared Grebes and Double-crested Cormorants.

Our surveys on Buffalo Lake considered only breeding birds during a single season. A more complete evaluation of priority wildlife habitats would include inventories of birds at other times of the year, during different years, and would also include proper consideration of other wildlife groups, including fish, invertebrates and plants. Many of these species are of high importance to resource managers because of their conservation status, and because of their value to humans. Proper consideration of these groups will help ensure that Buffalo Lake will continue to support essential wildlife habitats in the face of accelerating human development.

\section{LITERATURE CITED}

Alberta Piping Plover Recovery Team. 2006. Alberta Piping Plover recovery plan 20052010. Alberta Sustainable Resource Development, Fish and Wildlife Division, Alberta Species Recovery Plan No. 10. Edmonton, AB. 27 pp.

Alberta Sustainable Resource Development. 2007. The 2005 general status of Alberta wild species. URL: $<$ http://www.srd.gov.ab.ca/fw/wildspecies/index.htm> [Updated January 2007].

Allen, J. R. 1987. Nesting survey on selected Great Blue Heron colonies in Central Region. Alberta Fish and Wildlife, Red Deer, AB. 21 pp. 
American Ornithologists' Union. 1998. Checklist of North American birds, 7th ed. American Ornithologists' Union, Washington, DC. 829 pp.

Berg, G. L., L. Wilkinson, H. Wollis, and D. Prescott. 2004. Western (Aechmophorus occidentalis) and Eared (Podiceps nigricollis) Grebes of central Alberta: 2004 field summary. Sustainable Resource Development, Fish and Wildlife Division, Alberta Species at Risk Report No. 94, Edmonton, AB. 17 pp.

Beyersbergen, G.W., N. D. Niemuth and M. R. Norton. 2004. Northern prairie and parkland waterbird conservation plan. U. S. Fish and Wildlife Service, Denver, Colorado. $57 \mathrm{pp}$.

Bjorge, R. R. 1992. An investigation of colonial nesting birds at Buffalo Lake, Alberta 1992. Unpubl. rept., Alberta Fish and Wildlife Division, Central Region, Red Deer, AB. $6 \mathrm{pp}$.

Cottonwood Consultants Ltd. 2000. American White Pelican, California Gull, Caspian Tern, Double-crested Cormorant, Great Blue Heron and Ring-billed Gull surveys Alberta 1998. Volume1 - Report (with 1999 update). North American Waterfowl Management Plan, Alberta Environment and Alberta Conservation Association, Edmonton, AB. 167 pp.

Environmental Management Associates. 1991. Parlby Creek - Buffalo Lake development project. Environmental impact assessment. Volume 2 - Main report. Environmental Management Associates, Calgary, AB. 422 pp. + appendices.

Goossen, J. P., S. M. Westworth, B. Yee, D. Thorson and I. Michaud. 2000. Atlas of Piping Plovers in the Canadian prairie provinces and Ontario. Multimedia CD-ROM atlas produced by Environment Canada, Edmonton, AB and Regina, SK.

Gray, B. T., S. Marken, K. Wilkinson, and D. A. Young. 1992. Parlby Creek-Buffalo Lake projects. 1992 biological studies. Environmental Management Associates, Calgary, AB. 121 pp. + appendices.

Hamilton, I. M., J. L. Skilnick, H. Troughton, AP. P. Russell, and G. L. Powell. 1998. Status of the Canadian Toad in Alberta. Alberta Environmental Protection, Wildlife Management Division, and Alberta Conservation Association, Wildlife Status Report No 12., Edmonton, AB. 30 pp.

Mitchell, P., and E. Prepas (eds.). Atlas of Alberta lakes. University of Alberta Press, Edmonton, AB. 675 pp.

Poston, B., D. M. Ealey, P. S. Taylor, and G. B. McKeating. 1990. Priority migratory bird habitats of Canada's prairie provinces. Canadian Wildlife Service, Edmonton, AB. $107 \mathrm{pp}$. 
Potter, J., K. Froggatt, R. Bjorge, and J. Skelton. 2003. Buffalo Lake shoreline and wildlife habitat assessment - 2002. Unpubl. rept., Alberta Fish and Wildlife Division and Alberta Conservation Association, Red Deer, AB. 124 pp.

Ralph, C.J., J. R. Sauer, and S. Droege (eds.). Monitoring bird populations by point counts. U.S. Dept. Agr., Gen. Tech Rept. PSW-GTR-149. 181 pp.

Semenchuk, G. P. 1992. The atlas of breeding birds of Alberta. Federation of Alberta Naturalists, Edmonton, AB. 391 pp.

Strong, W. L., and K. R. Leggat. 1981. Ecoregions of Alberta. Technical Report T/4, Alberta Energy and Natural Resources, Edmonton, AB. 64 pp. 


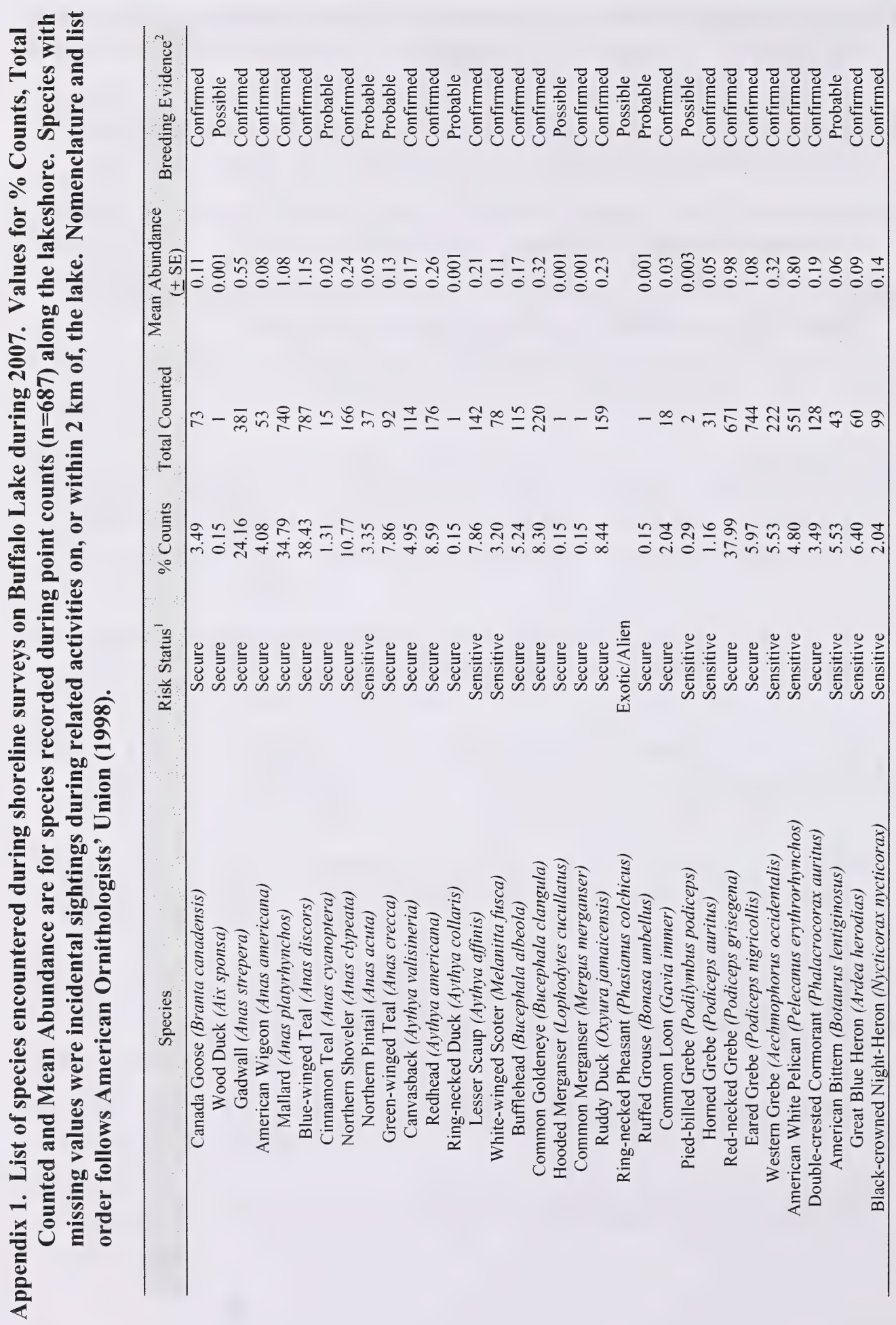




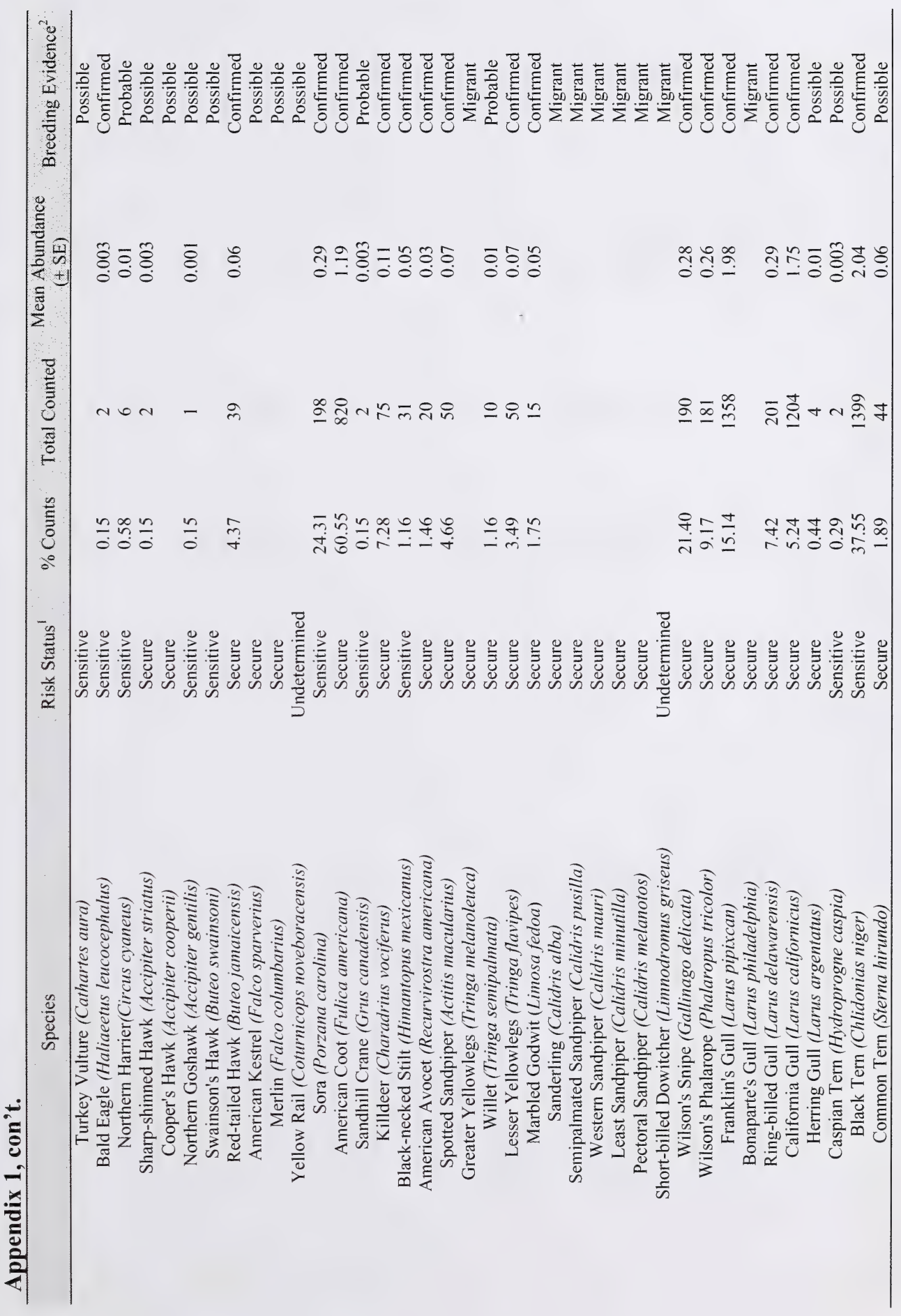




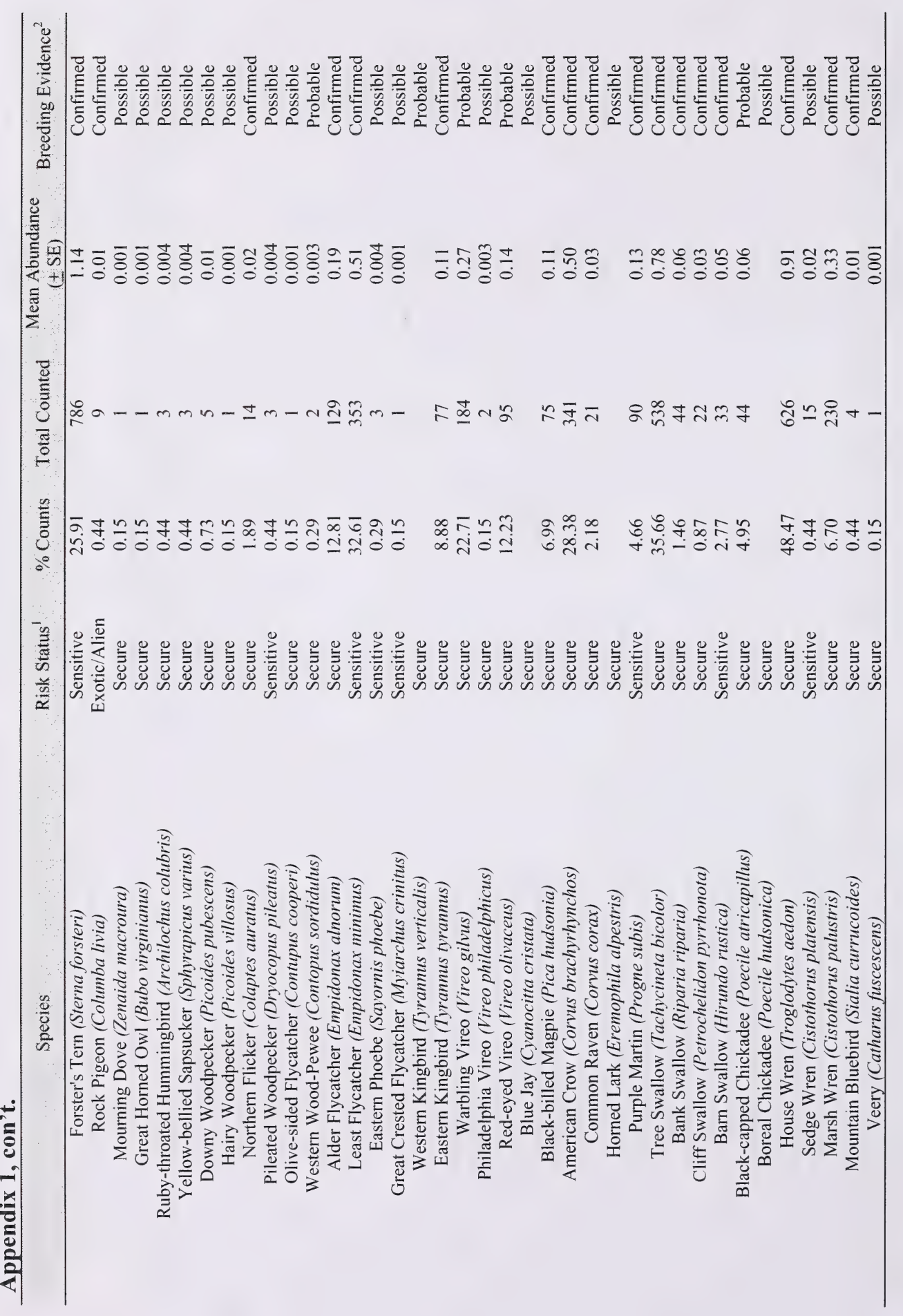




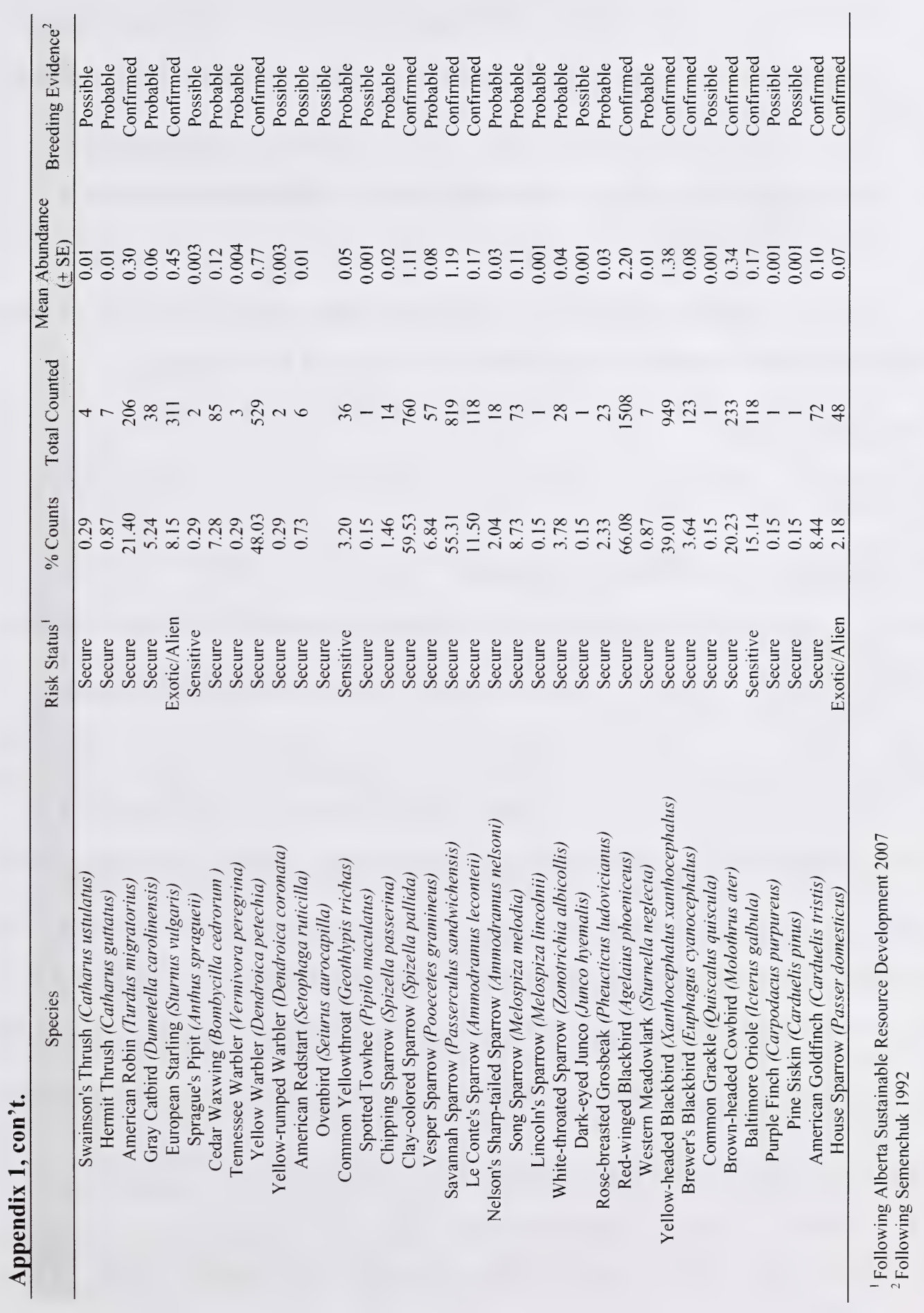




\section{List of Titles in This Series}

(as of November 2007)

No. 1 Alberta species at risk program and projects 2000-2001, by Alberta Sustainable Resource Development, Fish and Wildlife Division. (2001)

No. 2 Survey of the peregrine falcon (Falco peregrinus anatum) in Alberta, by R. Corrigan. (2001)

No. 3 Distribution and relative abundance of the shortjaw cisco (Coregonus zenithicus) in Alberta, by M. Steinhilber and L. Rhude. (2001)

No. 4 Survey of the bats of central and northwestern Alberta, by M.J. Vonhof and D. Hobson. (2001)

No. 52000 survey of the Trumpeter Swan (Cygnus buccinator) in Alberta, by M.L. James and A. James. (2001)

No. 6 2000/2001 Brassy Minnow inventory at Musreau Lake and outlet, by T. Ripley. (2001)

No. 7 Colonial nesting waterbird survey in the Northwest Boreal Region - 2000, by M. Hanneman and M. Heckbert. (2001)

No. 8 Burrowing owl trend block survey and monitoring - Brooks and Hanna areas, by D. Scobie and R. Russell. (2000)

No. 9 Survey of the Lake Sturgeon (Acipenser fulvescens) fishery on the South Saskatchewan River, Alberta (June-September, 2000), by L.A. Winkel. (2000)

No. 10 An evaluation of grizzly bear-human conflict in the Northwest Boreal Region of Alberta (1991-2000) and potential mitigation, by T. Augustyn. (2001)

No. 11 Harlequin duck monitoring in the Northern East Slopes of Alberta: 1998-2000 preliminary results, by J. Kneteman and A. Hubbs. (2000)

No. 12 Distribution of selected small mammals in Alberta, by L. Engley and M. Norton. (2001)

No. 13 Northern leopard frog reintroduction. Raven River - Year 2 (2000), by K. Kendell. (2001)

No. 14 Cumulative effects of watershed disturbances on fish communities in the Kakwa and Simonette watersheds. The Northern Watershed Project. Study 3 Progress report, by T. Thera and A. Wildeman. (2001)

No. 15 Harlequin duck research in Kananaskis Country in 2000, by C.M. Smith. (2001)

No. 16 Proposed monitoring plan for harlequin ducks in the Bow Region of Alberta, by C.M. Smith. (2001)

No. 17 Distribution and relative abundance of small mammals of the western plains of Alberta as determined from great horned owl pellets, by D. Schowalter. (2001)

No. 18 Western blue flag (Iris missouriensis) in Alberta: a census of naturally occurring populations for 2000, by R. Ernst. (2000)

No. 19 Assessing chick survival of sage grouse in Canada, by C.L. Aldridge. (2000)

No. 20 Harlequin duck surveys of the Oldman River Basin in 2000, by D. Paton. (2000)

No. 21 Proposed protocols for inventories of rare plants of the Grassland Natural Region, by C. Wallis. (2001) 
No. 22 Utilization of airphoto interpretation to locate prairie rattlesnake (Crotalus viridis viridis) hibernacula in the South Saskatchewan River valley, by J. Nicholson and S. Rose. (2001)

No. 23 2000/2001 Progress report on caribou research in west central Alberta, by T. Szkorupa. (2001)

No. 24 Census of swift fox (Vulpes velox) in Canada and Northern Montana: 2000-2001, by A. Moehrenschlager and C. Moehrenschlager. (2001)

No. 25 Population estimate and habitat associations of the long-billed curlew in Alberta, by E.J. Saunders. (2001)

No. 26 Aerial reconnaissance for piping plover habitat in east-central Alberta, May 2001, by D.R.C. Prescott. (2001)

No. 27 The 2001 international piping plover census in Alberta, by D.R.C. Prescott. (2001)

No. 28 Prairie rattlesnake (Crotalus viridis viridis) monitoring in Alberta - preliminary investigations (2000), by S.L. Rose. (2001)

No. 29 A survey of short-horned lizard (Phrynosoma hernandesi hernandesi) populations in Alberta, by J. James. (2001)

No. 30 Red-sided garter snake (Thamnophis sirtalis parietalis) education and relocation project - final report, by L. Takats. (2002)

No. 31 Alberta furbearer harvest data analysis, by K.G. Poole and G. Mowat. (2001)

No. 32 Measuring wolverine distribution and abundance in Alberta, by G. Mowat. (2001)

No. 33 Woodland caribou (Rangifer tarandus caribou) habitat classification in northeastern Alberta using remote sensing, by G.A. Sanchez-Azofeifa and R. Bechtel. (2001)

No. 34 Peregrine falcon surveys and monitoring in the Parkland Region of Alberta, 2001, by R. Corrigan. (2002)

No. 35 Protocol for monitoring long-toed salamander (Ambystoma macrodactylum) populations in Alberta, by T. Pretzlaw, M. Huynh, L. Takats and L. Wilkinson. (2002)

No. 36 Long-toed salamander (Ambystoma macrodactylum) monitoring study in Alberta: summary report 19982001, by M. Huynh, L. Takats and L. Wilkinson. (2002)

No. 37 Mountain plover habitat and population surveys in Alberta, 2001, by C. Wershler and C. Wallis. (2002)

No. 38 A census and recommendations for management for western blue flag (Iris missouriensis) in Alberta, by R. Ernst. (2002)

No. 39 Columbian mountain amphibian surveys, 2001, by D. Paton. (2002)

No. 40 Management and recovery strategies for the Lethbridge population of the prairie rattlesnake, by R. Ernst. (2002)

No. 41 Western (Aechmophorus occidentalis) and eared (Podiceps nigricollis) grebes of central Alberta: inventory, survey techniques and management concerns, by S. Hanus, H. Wollis and L. Wilkinson. (2002)

No. 42 Northern leopard frog reintroduction - year 3 (2001), by K. Kendell. (2002)

No. 43 Survey protocol for the northern leopard frog, by K. Kendell. (2002) 
No. 44 Alberta inventory for the northern leopard frog (2000-2001), by K. Kendell. (2002)

No. 45 Fish species at risk in the Milk and St. Mary drainages, by RL\&L Environmental Services Ltd. (2002)

No. 46 Survey of the loggerhead shrike in the southern aspen parkland region, 2000-2001, by H. Kiliaan and D.R.C. Prescott. (2002)

No. 47 Survey of native grassland butterflies in the Peace parkland region of northwestern Alberta - 2001, by M. Hervieux. (2002)

No. 48 Caribou range recovery in Alberta: 2001/02 pilot year, by T. Szkorupa. (2002)

No. 49 Peace parkland native grassland stewardship program 2001/02, by A. Baker. (2002)

No. 50 Carnivores and corridors in the Crowsnest Pass, by C. Chetkiewicz. (2002)

No. 512001 Burrowing owl trend block survey and monitoring, Brooks and Hanna areas, by D. Scobie. (2002)

No. 52 An evaluation of the ferruginous hawk population in Alberta based on recent trend data, by D.P. Stepnisky, G.L. Erickson, J. Iwaasa and B. Taylor. (2002)

No. 53 Alberta amphibian call surveys. A pilot year. Final report, by L. Takats and C. Priestley. (2002)

No. 54 Utilization of a roadside survey technique to survey burrowing owl (Athene cunicularia hypugaea) in southeastern Alberta, by J. Nicholson and C. Skiftun. (2002)

No. 55 Alberta species at risk program and projects 2001-2002, by Alberta Sustainable Resource Development, Fish and Wildlife Division. (2002)

No. 56 Developing a habitat-based population viability model for greater sage-grouse in southeastern Alberta, by C.L. Aldridge. (2001)

No. 57 Peregrine falcon surveys and monitoring in the Northeast Boreal Region of Alberta, 2001, by R. Corrigan. (2002)

No. 582002 burrowing owl trend block survey and monitoring, Brooks area, by R.F. Russell. (2002)

No. 59 Rare plant inventory of the eastern edge of the lower foothills natural subregion, west-central Alberta, by J. Doubt. (2002)

No. 60 Western (Aechmophorus occidentalis) and eared (Podiceps nigricollis) grebes of central Alberta: 2002 field summary, by S. Hanus, L. Wilkinson and H. Wollis. (2002)

No. 61 Inventory of western spiderwort (Tradescantia occidentalis) in Alberta: 2002, by S. Peters. (2003)

No. 62 Bullsnakes (Pituophis catenifer sayi) in Alberta: literature review and data compilation, by K.J. Kissner and J. Nicholson. (2003)

No. 63 Distribution of Ord's kangaroo rats in southeastern Alberta, by D.L. Gummer and S.E. Robertson. (2003)

No. 64 Lethbridge prairie rattlesnake conservation project: 2002/2003 progress report, by R.D. Ernst. (2003)

No. 65 Short-horned lizard (Phrynosoma hernandesi hernandesi) populations in Alberta - 2002 survey results, by J.D. James. (2003) 
No. 66 Inventory and monitoring protocol for naturally occurring western blue flag (Iris missouriensis) in Alberta, by R.D. Ernst. (2003)

No. 67 The use of call playbacks for censusing loggerhead shrikes in southern Alberta, by D.R.C. Prescott. (2003)

No. 68 Survey of bats in northeastern Alberta, by A. Hubbs and T. Schowalter. (2003)

No. 69 Survey protocol for the Richardson's ground squirrel, by B.A. Downey. (2003)

No. 70 Population estimates and a survey protocol for ferruginous hawks in Alberta, by B.N. Taylor. (2003)

No. 71 Testing methods for detecting wolverine, by G. Mowat, C. Kyle and D. Paetkau. (2003)

No. 72 A multi-species conservation strategy for species at risk in the Milk River basin: year 1 progress report, by R.W. Quinlan, B.A. Downey, B.N. Taylor, P.F. Jones and T.B. Clayton. (2003)

No. 73 Long-toed salamander (Ambystoma macrodactylum) conservation in the Alberta foothills: 2002 field summary report, by L. Wilkinson and S. Hanus. (2003)

No. 74 Researching Amphibian Numbers in Alberta (RANA): 2002 provincial summary, by L. Wilkinson and S. Hanus. (2003)

No. 75 Distribution and habitat associations of the long-toed salamander (Ambystoma macrodactylum) in the Oldman River drainage, by K. Pearson. (2003)

No. 76 Prairie rattlesnake (Crotalus viridis) hibernacula: monitoring history in Alberta 1987-2002, by K.J. Kissner and J. Nicholson. (2003)

No. 77 Alberta species at risk program and projects 2002-2003, by Alberta Sustainable Resource Development, Fish and Wildlife Division. (2003)

No. 78 Northern leopard frog reintroduction: Year 4 (2002), by K. Kendell. (2003)

No. 79 Magrath Northern Leopard Frog Reintroduction Project - Year 1 Progress Report, by K.A. Romanchuck. (2003)

No. 80 Conservation Overview of Butterflies in the Southern Headwaters at Risk Project (SHARP) Area, by N. Kondla. (2004)

No. 81 Lethbridge Rattlesnake Conservation Project: 2003 Progress Report, by R. Ernst. (2004)

No. 82 Shortjaw Cisco Species at Risk Assessment 2001, by M. Steinhilber. (2004)

No. 83 Researching Amphibian Numbers in Alberta (RANA): 2003 provincial summary, by L. Wilkinson and K. Kempin. (2004)

No. 84 Methods for Controlling Depredation on Piping Plovers in Alberta: A Literature Review and Synthesis, by R. Schmelzeisen, D.R.C. Prescott and L. Engley. (2004)

No. 85 Western Blue Flag Conservation Program: 3-Year Summary Report, by K.A. Romanchuk, R.D. Ernst, and R.W Quinlan (2004)

No. 86 MULTISAR: The Milk River Basin Habitat Suitability Models for Selected Wildlife Management Species, by B. A. Downey, B. L. Downey, R. W. Quinlan, O. Castelli, V. Remesz and P. F. Jones (eds.). (2004) 
No. 87 MULTISAR: The Milk River Basin, A Multi-Species Conservation Strategy For Species at Risk: Year 2Progress Report, by R.W. Quinlan, B. A. Downey, B. L. Downey, and P. F. Jones. (2004)

No. 88 Survey of Colonial Nesting Birds and Lakeshore Habitats in Northeast Alberta, by C. Found and A. Hubbs. (2004)

No. 89 The southern headwaters at risk project: A multi-species conservation strategy for the headwaters of the Oldman River. Volume 1: Introduction and natural processes, by F. Blouin. (2004)

No. 90 The southern headwaters at risk project: A multi-species conservation strategy for the headwaters of the Oldman River. Volume 2: Species Selection and Habitat Suitability Models, by F. Blouin, B.N.Taylor, and R.W.Quinlan (eds). (2004)

No. 91 Distribution, abundance and habitat selection of northern pygmy and barred owls along the eastern slopes of the Alberta Rocky Mountains, by M. D. Piorecky and D. R. C. Prescott. (2004)

No. 92 Survey of Aquatic Gastropods in the Central Parkland Subregion of Alberta, by D. R. C. Prescott, and M. M. Curteanu. (2004)

No. 93 The 2003 Loggerhead Shrike Survey in Alberta, by D. R. C. Prescott. (2004)

No. 94 Western (Aechmophorus occidentalis) and Eared (Podiceps nigricollis) Grebes of Central and Parkland Alberta: 2004 Field Summary, by G. Berg, L. Wilkinson, H. Wollis, and D. Prescott. (2004)

No. 95 Researching Amphibian Numbers in Alberta (RANA): 2004 provincial summary, by L. Wilkinson and G. Berg. (2004)

No. 96 Gillett's checkerspot in the southern headwaters at risk (SHARP) project area, by N.G. Kondla. (2005)

No. 97 Southern headwaters at risk project (SHARP) amphibian and western painted turtle (Chrysemys picta) surveys, 2003-2004, by K.J. Pearson. (2005)

No. 98 MULTISAR: A Multi-Species Conservation Strategy For Species at Risk: Year 3 Report, by B. L. Downey, B. A. Downey, R.W. Quinlan, and P. F. Jones. (2005)

No. 99 Implementation of the Alberta Piping Plover Recovery Plan, 2002-2004: Final Program Report, Alberta Piping Plover Recovery Team. (2005)

No. 100 Alberta Species at Risk Program and Projects 2003-2004, by Alberta Sustainable Resource Development, Fish and Wildlife Division. (2005)

No. 101 The 2005 ferruginous hawk inventory and population analysis, by B. L. Downey. (2005)

No. 102 Western Spiderwort (Tradescantia occidentalis) Inventory in Alberta, 2005, by B.L. Remarchuk. (2006)

No. 103 Reproductive Biology of Female Prairie Rattlesnakes (Crotalus viridis viridis) in Alberta, by D. Jorgenson. (2007)

No. 104 Magrath Northern Leopard Frog Reintroduction Program: Final Report, by K. Romanchuk and R. Quinlan. (2005)

No. 105 The Southern Headwaters at Risk Project: A Multi-Species Conservation Strategy for the Headwaters of the Oldman River, Volume 3, Landscape Management - Selection and Recommendations, by F. Blouin. (2006) 
No. 106 The Southern Headwaters at Risk Project: A Multi-Species Conservation Strategy for the Headwaters of the Oldman River Volume 4, BMP's and Land Use Guidelines for Focal Species, by F. Blouin. (2006)

No. 107 The Southern Headwaters at Risk Project: A Multi-Species Conservation Strategy for the Headwaters of the Oldman River, Volume 5, Landscape Pressures on Wide-ranging Species, by F. Blouin. (2006)

No. 108 MULTISAR: A Multi-Species Conservation Strategy for Species at Risk 2005-2006 Report, by B. A. Downey, B. L. Downey, R. W. Quinlan, and P.F. Jones. (2006)

No. 109 Western Rattlers and People: Conserving rattlesnakes in Lethbridge, by R.D. Ernst and R.W. Quinlan. (2006)

No. 110 Researching Amphibian Numbers in Alberta (RANA): 2005 Provincial Summary, by L. Wilkinson and G. Berg. (2006)

No. 111 Inventory of the Pinhorn Soapweed (Yucca glauca) and Yucca moth (Tegiticula yuccasella) population, 2004, by K. Foreman, J. Chandler, and L. Matthias. (2006)

No. 113 Monitoring Protocol for the Ord's Kangaroo Rat, by D. J. Bender, D. L. Gummer, and R. Dzenkiw. (2007)

No. 114 MULTISAR: A Multi-species Conservation Strategy for Species at Risk, 2006-2007 report, by Downey, B. A., R. W. Quinlan, P. F. Jones, and R. Elhert. (2007) 

LIBRARY AND ARCHIVES CANADA

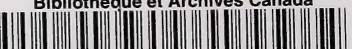

33286535286252 